\title{
Internal structure of event layers preserved on the Andaman Sea continental shelf, Thailand: tsunami vs. storm and flash-flood deposits
}

\author{
D. Sakuna-Schwartz ${ }^{1, *}$, P. Feldens ${ }^{1}$, K. Schwarzer ${ }^{1}$, S. Khokiattiwong ${ }^{2}$, and K. Stattegger ${ }^{1}$ \\ ${ }^{1}$ Institute of Geosciences, Kiel University, Otto-Hahn-Platz 1, 24118 Kiel, Germany \\ ${ }^{2}$ Oceanography Unit, Phuket Marine Biological Center, P.O. Box 60, Phuket 83000, Thailand \\ *now at: Oceanography Unit, Phuket Marine Biological Center, P.O. Box 60, Phuket 83000, Thailand
}

Correspondence to: D. Sakuna-Schwartz (daroonwans@gmail.com)

Received: 10 September 2014 - Published in Nat. Hazards Earth Syst. Sci. Discuss.: 1 December 2014 Accepted: 20 May 2015 - Published: 12 June 2015

\begin{abstract}
Tsunami, storm and flash-flood event layers, which have been deposited over the last century on the shelf offshore Khao Lak (Thailand, Andaman Sea), are identified in sediment cores based on sedimentary structures, grain size compositions, $\mathrm{Ti} / \mathrm{Ca}$ ratios and ${ }^{210} \mathrm{~Pb}$ activity. Individual offshore tsunami deposits are 12 to $30 \mathrm{~cm}$ in thickness and originate from the 2004 Indian Ocean Tsunami. They are characterized by (1) the appearance of sand layers enriched in shells and shell debris and (2) the appearance of mud and sand clasts. Storm deposits found in core depths between 5 and $82 \mathrm{~cm}$ could be attributed to recent storm events by using ${ }^{210} \mathrm{~Pb}$ profiles in conjunction with historical data of typhoons and tropical storms. Massive sand layers enriched in shells and shell debris characterize storm deposits. The last classified type of event layer represents reworked flash-flood deposits, which are characterized by a fining-upward sequence of muddy sediment. The most distinct difference between storm and tsunami deposits is the lack of mud and sand clasts, mud content and terrigenous material within storm deposits. Terrigenous material transported offshore during the tsunami backwash is therefore an important indicator to distinguish between storm and tsunami deposits in offshore environments.
\end{abstract}

\section{Introduction}

Tsunami waves propagating into shallow waters as well as related backwash flows can erode, transport and deposit significant amounts of sediments in the inner-shelf environment (e.g., Paris et al., 2010; Goto et al., 2011), here defined as 0 to $30 \mathrm{~m}$ water depth. The behavior of tsunami waves is controlled by the source earthquake or landslide and the ocean basin's morphology on a larger scale, and by the inner shelf and coastal bathymetry as well as the hydrological conditions on a local scale (Cheng and Weiss, 2013; Spiske et al., 2013; Goto et al., 2014). Coastal and inner-shelf bathymetry is the most important factor controlling backwash flow (Le Roux and Vargas, 2005; Paris et al., 2010; Feldens et al., 2012; Spiske et al., 2014).

The structure and texture of tsunami deposits in offshore areas mainly depend on the local sediment sources, the geomorphology of the seafloor, the tsunami wave height and the number of waves in the case of more than one wave hitting the shoreline during the run-up and backwash (Sakuna et al., 2012). Both the bathymetry and available sediments are highly variable in shallow marine environments (e.g., Dartnell and Gardner, 2004). A complex composition of offshore tsunami deposits is therefore expected, with potentially quick changes both in space and time (Shanmugam, 2011). A tsunami's impact in deeper waters may be preserved within sediments below the storm wave base (e.g., Weiss and Bahlburg, 2006; Weiss, 2008). However, while the tsunami's impact increases with decreasing water depth towards the coastline, only very few offshore tsunami deposits have been 
reported until now. Therefore, it is not surprising that the described offshore deposits of historical tsunami - not considering inferred tsunami paleorecords on geological timescales (Le Roux and Vargas, 2005; Fujiwara and Kamataki, 2007; Spiske et al., 2014) - are highly variable in thickness, texture and structure (e.g., van den Bergh et al., 2003; Abrantes et al., 2008; Goodman-Tchernov et al., 2009; Paris et al., 2010; Smedile et al., 2011; Sakuna et al., 2012; Milker et al., 2013). Reported offshore tsunami deposits range from centimeters to $1 \mathrm{~m}$ in thickness while spanning grain sizes from mud to boulders, including terrigenous and marine sediments over one or several layers. The depositions are composed of different fossil assemblages and different sedimentary structures (Sakuna et al., 2012). One reason for the scarcity of reported offshore tsunami deposits is their potentially low preservation in shallow waters due to reworking and transport by currents, waves (Weiss and Bahlburg, 2006), tides and gravity flows which disperse sediment and shape continental shelf settings. Reworking of event layers is intensified by bioturbation especially in areas with low accumulation rates, where deposits cannot quickly escape the surface mixing layer (Wheatcroft and Drake, 2003).

A further problem is the differentiation of tsunami layers from other event-related deposition and accumulation, with storms and flash floods arguably most important in innercontinental-shelf settings. The differentiation of tsunami deposits from tempestites has been widely discussed for deposits left on land (e.g., Nott, 2003; Goff et al., 2004; Kortekaas and Dawson, 2007; Morton et al., 2007; Switzer and Jones, 2008; Lario et al., 2010; Lorang, 2011; Richmond et al., 2011; Phantuwongraj and Choowong, 2012; RamírezHerrera et al., 2012; Brill et al., 2014a). However, there is no consensus yet on reliable sedimentological criteria to distinguish between offshore storm and tsunami deposits. Generally, shallow-water, proximal tempestites are characterized by basal erosional contacts and a sequence from normal gradation to cross-stratification to plane lamination, with frequently preserved ripples at the top (Einsele et al., 1991; Allison et al., 2005). Not all tempestites comprise all these features, and they may also be observed in offshore tsunami deposits (Sakuna et al., 2012). Flash floods can comprise a large percentage of a river's yearly discharge and can form hyperpycnal flows due to high suspension load (Mulder et al., 2003; Bourrin et al., 2008). These criteria have also been established for tsunami backwash flows (Le Roux and Vargas, 2005). In monsoon-dominated areas, flash-flood deposits occur frequently in front of river mouths or through ephemeral streams (Kale, 2003; Malmon et al., 2004). Their deposits have to be considered while identifying offshore backflow tsunami deposits. Flash-flood deposits are typically coarsegrained (Postma, 2001) or alternating sand and mud layers (Martin, 2000), but they also comprise stratified deposits of silty clay within mud belts (Cutter and Diaz, 2000; Hill et al., 2007).
The Andaman Sea (Thailand) is an area where tsunami, storm and flash-flood deposits can be studied. It was subjected to few strong storms over the last decades and is regularly impacted by the northeast and southwest monsoons, with the latter causing flash floods. It was strongly affected by the 2004 Indian Ocean Tsunami, and preserved event deposits are accessible closely beneath the surface of the seafloor due to low riverine sediment delivery. Based on a collection of six sediment cores, the objectives of this study are to (a) identify, describe and discuss tsunami, storm and flash-flood deposits in sediment cores and (b) to identify proxies that can be used to distinguish tsunami, storm and flash-flood deposits from each other.

\section{Regional setting}

The investigation area near Pakarang Cape (hereafter PC) is located on the western side of the southern ThaiMalay Peninsula offshore Phang Nga province (Fig. 1). The Ayeyarwady-Salween river system is the main source supplying fine-grained sediment into the Andaman Sea (Rodolfo, 1969; Colin et al., 1999), which is highly seasonal with more than $80 \%$ of the annual discharging during the SW monsoon (Ramaswamy et al., 2004). The majority of the Andaman shelf is classified as sediment starved (Rodolfo, 1969; Panchang et al., 2008; Schwab et al., 2012). The coastline north and south of PC represents an embayed coast with sandy beaches commonly separated by rocky headlands. In general, the shelf gently dips offshore, reaching $60 \mathrm{~m}$ water depths within a distance of $30 \mathrm{~km}$ from the coastline. PC itself is surrounded by a $3 \mathrm{~km}$ long reef platform (Goto et al., 2007; Choowong et al., 2009; Di Geronimo et al., 2009). The tides in this area are mixed semidiurnal tides, with most days having two high tides and two low tides. The mean tidal range extends from $1.1 \mathrm{~m}$ during neap tide to $3.6 \mathrm{~m}$ during spring tide (Thampanya et al., 2006). Based on geomorphological evidence from sandy hooks and spits, northwarddirected current-induced longshore sediment transport occurs in the study area (Choowong et al., 2009; Brill et al., 2014b). Maps of the nearshore bathymetry and sediment distribution have been created following the 2004 Indian Ocean Tsunami (e.g., Di Geronimo et al., 2009; Feldens et al., 2009, 2012), but these maps cover only a small percentage of the Andaman Sea Shelf. According to these studies, mud patches are widespread in water depths between 5 and $15 \mathrm{~m}$ north and south of PC. Several granite outcrops are scattered along the inner shelf at water depths of $5-10 \mathrm{~m}$ and on the midshelf at a water depth of approximately $30 \mathrm{~m}$. Extensive cassiterite mining both on- and offshore affected the area over the last century (Hylleberg et al., 1985; Usiriprisan et al., 1987). Offshore, visible remnants of the mining activities include up to $7 \mathrm{~m}$ deep holes at water depths of $20-25 \mathrm{~m} \mathrm{NW}$ of PC (Feldens et al., 2009). 


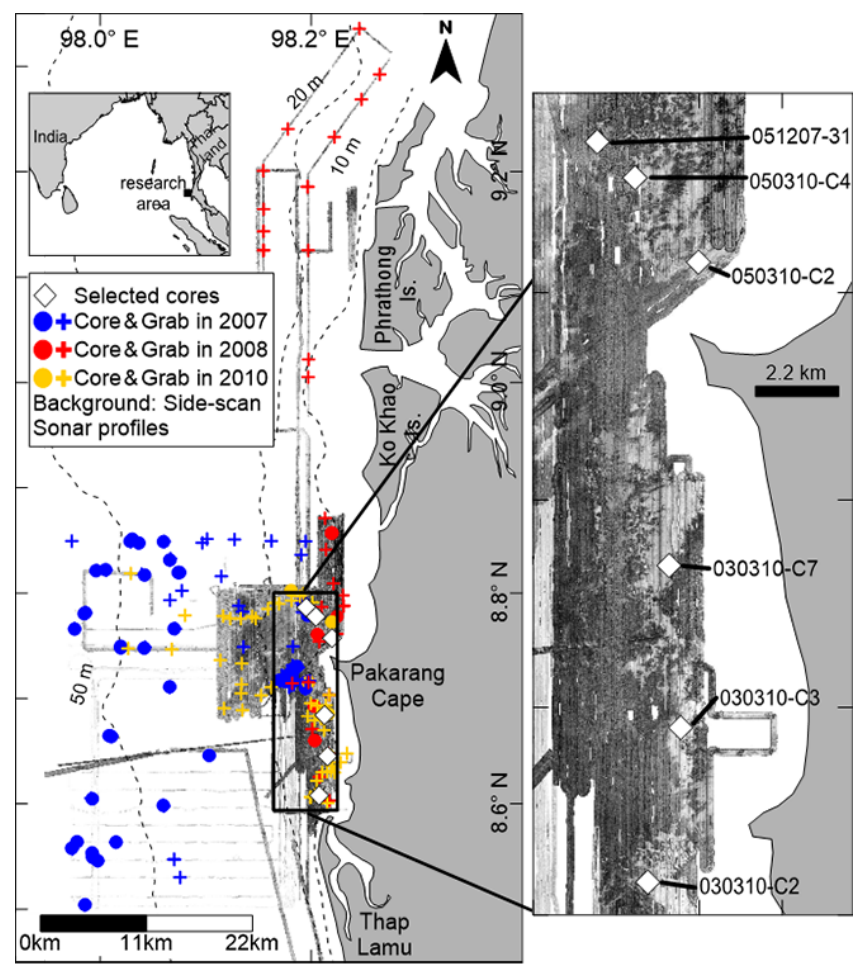

Figure 1. Overview map of the investigation area including sampling stations. The bathymetric data are based on nautical charts. The sediment samples taken during the 3-year research period on the three different cruises are presented in difference colors.

The climate of this region is influenced by the tropical monsoon, with the northeast monsoon lasting from December to February, causing dry weather conditions, and the southwest monsoon lasting from May to September, bringing strong westerly winds and heavy rainfall (Khokiattiwong et al., 1991). While no studies on flash floods have been published for the Andaman Coast, they are expected to occur during the southwest monsoon (Lim and Boochabun, 2012) and have been reported by the local population. Storms and typhoons commonly form in the South China Sea during the northeast monsoon but tend to lose their energy while crossing the Thai-Malay Peninsula (data compiled by TMD, 2012). In additional, cyclone tracks originating within the Bay of Bengal are predominantly directed towards the coast of India, Bangladesh and Myanmar (Singh et al., 2000, Brill et al., 2011). The Andaman Shelf is therefore seldom affected by severe storms and typhoons, and only nine strong storm events have been recorded within a 180-nautical-mile radius of Phuket between 1945 and 1996 (Table 1).

The coastal area of the Andaman Sea was seriously affected by the 2004 Indian Ocean Tsunami (Chavanich et al., 2005; Siripong, 2006; Szczuciński et al., 2006; Choowong et al., 2007; Goto et al., 2007; Umitsu et al., 2007). Since then, several studies (Di Geronimo et al., 2009; Sugawara et al., 2009; Feldens et al., 2009, 2012) have focused on
Table 1. History of nine tropical storms and typhoons that approached within a 180-nautical-mile radius of Phuket during the 52-year period (1945-1996). Modified from the Typhoon Havens Handbook (Brand, 2009).

\begin{tabular}{lrr}
\hline Storm & Date & $\begin{array}{r}\text { Maximum wind speed } \\
\text { at storm center (knot) }\end{array}$ \\
\hline Harriet & 26 Oct 1962 & 30 \\
Lucy & 1 Dec 1962 & 20 \\
Gloria & 21 Dec 1965 & 30 \\
Sally & 5 Dec 1972 & 40 \\
Sarah & 12 Nov 1973 & 25 \\
Gay & 4 Nov 1989 & 100 \\
Forrest & 15 Nov 1992 & 55 \\
Manny & 16 Dec 1993 & 20 \\
Ernie & 18 Nov 1996 & 22 \\
\hline
\end{tabular}

the tsunami's impact on the shelf area offshore Khao Lak. Only little influence and few deposits related to the 2004 tsunami could be found 3 to 5 years later offshore between 5 and $70 \mathrm{~m}$ water depths (Di Geronimo et al., 2009; Sugawara et al., 2009; Feldens et al., 2012; Sakuna et al., 2012; Milker et al., 2013). Due to the reworking of shelf sediments (Sakuna et al., 2012) and the re-establishment of the coastline (Choowong et al., 2009; Grzelak et al., 2009) following the tsunami, the remaining offshore tsunami deposits have been chiefly found in locally sheltered positions adjacent to granitic outcrops, within an incised channel system and in areas of locally higher sediment accumulation rates (Feldens et al., 2012; Sakuna et al., 2012; Milker et al., 2013).

\section{Methods}

During three research cruises in December 2007, December 2008 and February-March 2010, side-scan sonar data were obtained using a Klein 595 side-scan sonar $(384 \mathrm{kHz})$ and a Benthos 1624 side-scan sonar (100 and $400 \mathrm{kHz}$ ). The instruments were towed behind the vessel with approximately 10 to $50 \mathrm{~m}$ offset from the GPS antenna. This offset was accounted for by a constant value for each profile when calculating the position of the tow fish. Side-scan sonar data were recorded in digital format, employing the Isis software package Triton Elics Int. The data were processed and geo-referenced using the same software to create side-scan sonar mosaics of the study area. In this study, areas of higher backscatter are displayed with darker colors.

A total of 60 gravity cores using a Rumohr-type gravity corer ( $8 \mathrm{~cm}$ diameter) were collected (see Fig. 1) based on the on-site interpretation of the side-scan sonar images and previous shallow seismic mapping (Feldens et al., 2009, 2012). Gravity cores could be retrieved only from fine-grained (silt and finer) seafloor sediments, as the corer could not penetrate into the seafloor composed of sand. In all the cores, the 
Table 2. List of the analyzed sediment cores.

\begin{tabular}{lrrrrrr}
\hline Core no. & $\begin{array}{r}\text { Sampling } \\
\text { year }\end{array}$ & $\begin{array}{r}\text { Latitude } \\
(\mathrm{N})\end{array}$ & $\begin{array}{r}\text { Longitude } \\
(\mathrm{E})\end{array}$ & $\begin{array}{r}\text { Water } \\
\text { depth }(\mathrm{m})\end{array}$ & $\begin{array}{r}\text { Core } \\
\text { recovery }(\mathrm{cm})\end{array}$ & $\begin{array}{r}\text { Distance } \\
\text { offshore }(\mathrm{km})\end{array}$ \\
\hline $051207-31$ & 2007 & $8^{\circ} 47.176^{\prime}$ & $98^{\circ} 11.724^{\prime}$ & 15.9 & 70 & 7.2 \\
$030310-\mathrm{C} 2$ & 2010 & $8^{\circ} 36.474^{\prime}$ & $98^{\circ} 12.454^{\prime}$ & 11.5 & 23 & 3.3 \\
030310-C3 & 2010 & $8^{\circ} 38.708^{\prime}$ & $98^{\circ} 12.931^{\prime}$ & 9.5 & 97 & 3.2 \\
$030310-\mathrm{C} 7$ & 2010 & $8^{\circ} 41.053^{\prime}$ & $98^{\circ} 12.763^{\prime}$ & 11.9 & 65 & 2.9 \\
$050310-\mathrm{C} 2$ & 2010 & $8^{\circ} 45.438^{\prime}$ & $98^{\circ} 13.186^{\prime}$ & 9.8 & 75 & 4.1 \\
$050310-\mathrm{C} 4$ & 2010 & $8^{\circ} 46.659^{\prime}$ & $98^{\circ} 12.269^{\prime}$ & 15.3 & 55 & 6.3 \\
\hline
\end{tabular}

sediment water interface was preserved. The split sediment cores were first photographed and analyzed at a $1 \mathrm{~cm}$ interval in the laboratory according to the following scheme. A multi-sensor core logger (MSCL) was used to obtain data about physical sediment properties (Weber et al., 1997; Best and Gunn, 1999; Hofmann et al., 2005). Chemical element composition to differentiate between terrigenous versus marine constituents (Lamy et al., 2001; Bahr et al., 2005; Ohta and Arai, 2007; Tjallingi et al., 2010) was determined by an X-ray fluorescence (XRF) core scanner. The sediment slabs were radiographed to detect internal sedimentary structures and unconformities.

Six cores are presented in this study (Fig. 1, Table 2). For the selected cores, grain size composition was determined every $1 \mathrm{~cm}$ with a laser-based particle sizer device with a measuring range of 0.04 to $2000 \mu \mathrm{m}$. Therefore, grains larger than $2000 \mu \mathrm{m}$ were separated prior to the measurements. The statistical parameters of the grain size distributions were calculated in phi $(\Phi)$ units with $\Phi=-\log _{2} d(d$ being the grain size in mm; Krumbein, 1938), using the logarithmic method of moments available with the GRADISTAT software (Blott and Pye, 2001). Measurements of ${ }^{210} \mathrm{~Pb}$ activity were done for two sediment cores (030310-C3 and 050310-C4) to assess sediment accumulation rates. The sediment samples were dried, ground and analyzed using gamma spectrometry at the Leibniz Laboratory for Radiometric Dating and Isotope Research, Kiel, Germany. As the ${ }^{137} \mathrm{Cs}$ activity was mostly below the detection limits, it could not serve as an independent tracer. The sediment accumulation rate (SAR) was estimated from the decline in the excess ${ }^{210} \mathrm{~Pb}$ activity following the equations used by Robins and Edington (1975) and McKee et al. (1983).

$\mathrm{SAR}=\lambda \times z \times\left[\ln \left(A_{0} / A_{z}\right)\right]^{-1}$,

where $\lambda$ is the decay constant $\left(=0.0311\right.$ year $\left.^{-1}\right) ; z$ is the depth in the core $(\mathrm{cm}) ; A_{0}$ is the specific activity of excess ${ }^{210} \mathrm{~Pb}$ at a particular reference horizon $\left(\mathrm{Bq} \mathrm{kg}^{-1}\right)$; and $A_{z}$ is the specific activity of excess ${ }^{210} \mathrm{~Pb}$ at depth $z$ below the reference horizon $\left(\mathrm{Bq} \mathrm{kg}^{-1}\right)$.

\section{Results}

\subsection{Subsurface sediment sequence}

The description of the sediment sequence in the cores is based on structure and texture analyses of photos and Xradiographic images. The depth values in the following section refer to core depths. Core positions are indicated in Fig. 1, and an overview of all the available core details is given in Fig. 2, while the side-scan sonar data showing the sediment distribution from the areas where the cores have been taken are shown in Fig. 3. The sedimentary features and the interpretation of all the studied cores are summarized in Table 3 and Fig. 5.

\subsubsection{Core 030310-C3 (Fig. 2)}

Core 030310-C3 (97 cm in length) was collected $3.2 \mathrm{~km}$ offshore at a water depth of $9.5 \mathrm{~m}$, ca. $100 \mathrm{~m}$ west of a granitic outcrop (Fig. 3a). In the vicinity of the coring position, the backscatter in the side-scan sonar is low, representing silt and fine sand, proven by grab samples and grain size analyses.

The lowermost $2 \mathrm{~cm}$ of the core is composed of massive fine-grained sediment. At $95 \mathrm{~cm}$, an erosional contact with laminated sediments above exists. These laminated sediments extend up to $82 \mathrm{~cm}$ (facies D, Table 3a-VI). The laminations are slightly inclined, and the sediment is fining upward. Traces of bioturbation are not observed. Above a wavy and erosional contact at $82 \mathrm{~cm}$, a massive sand layer including few shells extends up to $79 \mathrm{~cm}$ (facies C, Table $3 \mathrm{a}-$ V). The upper boundary of this sand layer is sharp. Above, fining-upward, laminated mud extends from 79 to $70 \mathrm{~cm}$ (facies D). No traces of bioturbation are observed here either. Notably, a large sand clast can be observed from 77 to $73 \mathrm{~cm}$ in this core section. Laminations bend around the base of this clast and onlap at both sides. At $70 \mathrm{~cm}$, a sharp contact separates the laminated mud from a massive sand layer that extends up to $67 \mathrm{~cm}$ (facies C, Table 3a-IV). While half of its upper boundary appears transitional, this is likely related to disturbance (smearing) during the sampling procedure. Above $67 \mathrm{~cm}$, laminated sediment prevails up to $56 \mathrm{~cm}$ (facies D). Interbedded sand layers at $66 \mathrm{~cm}$, from 63 to $62 \mathrm{~cm}$ and from 61 to $60 \mathrm{~cm}$ show preserved wavy structures, each 

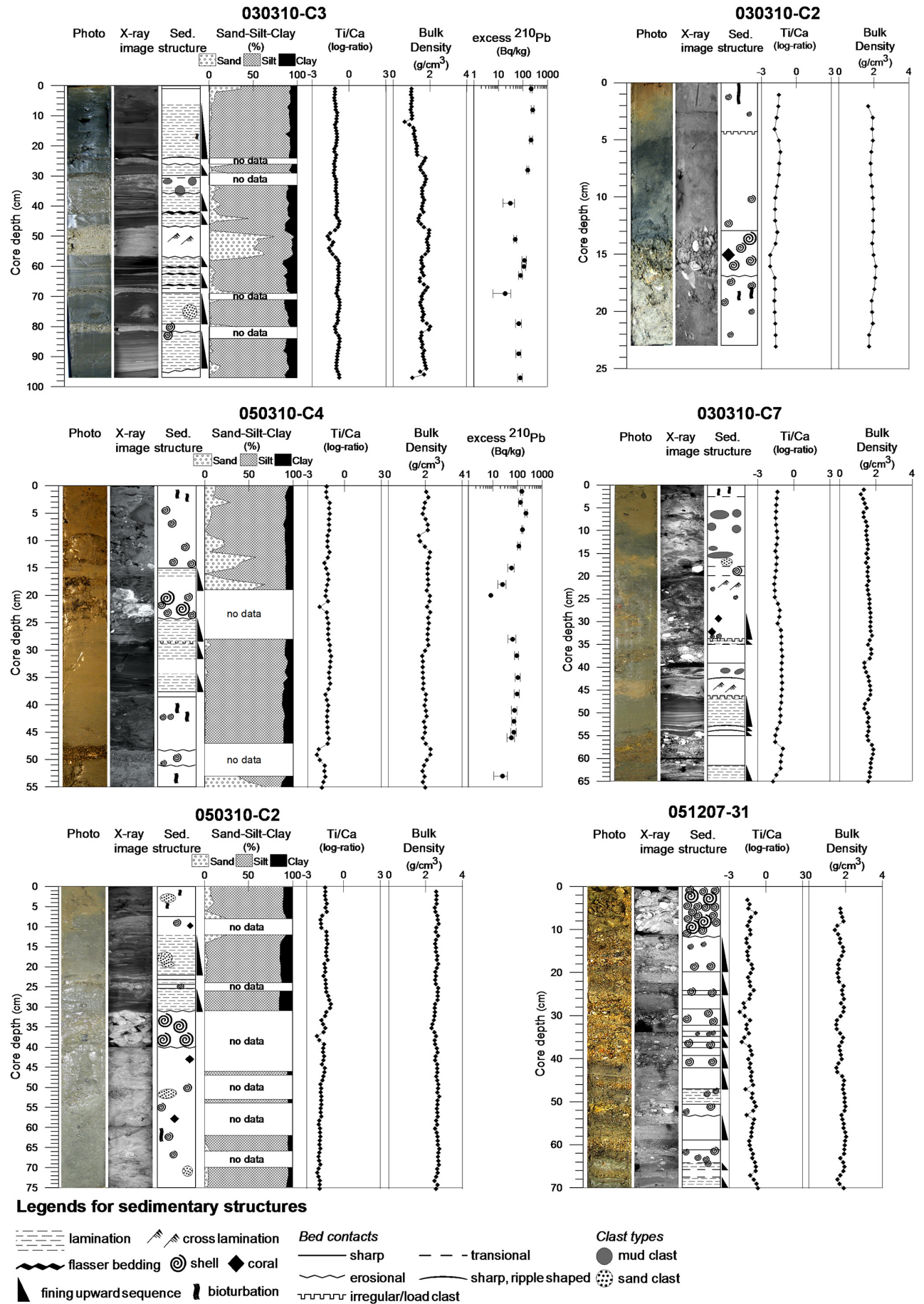

Figure 2. Interpretation of the sediment cores.

forming a sharp upper contact. An erosive unconformity separates a $9 \mathrm{~cm}$ thick laminated sand layer at $56 \mathrm{~cm}$ in which shells or bioturbation traces do not appear. The lower $4 \mathrm{~cm}$ of this sand layer appears massive (facies C, Table 3a-III). Above, laminated sediment is present from 47 to $36 \mathrm{~cm}$ (facies D), where it is terminated by an erosional boundary. In this interval, massive sand layers are interbedded from 43 to $42 \mathrm{~cm}$ with sharp upper and lower contacts, and from 39 to $38.5 \mathrm{~cm}$ layers with an irregularly sharp lower contact and a transitional upper contact are observed. Mud clasts have been found between 35 and $31 \mathrm{~cm}$ (facies B, Table 3a-II), with the diameter increasing in the upper layer. Above a tran- 

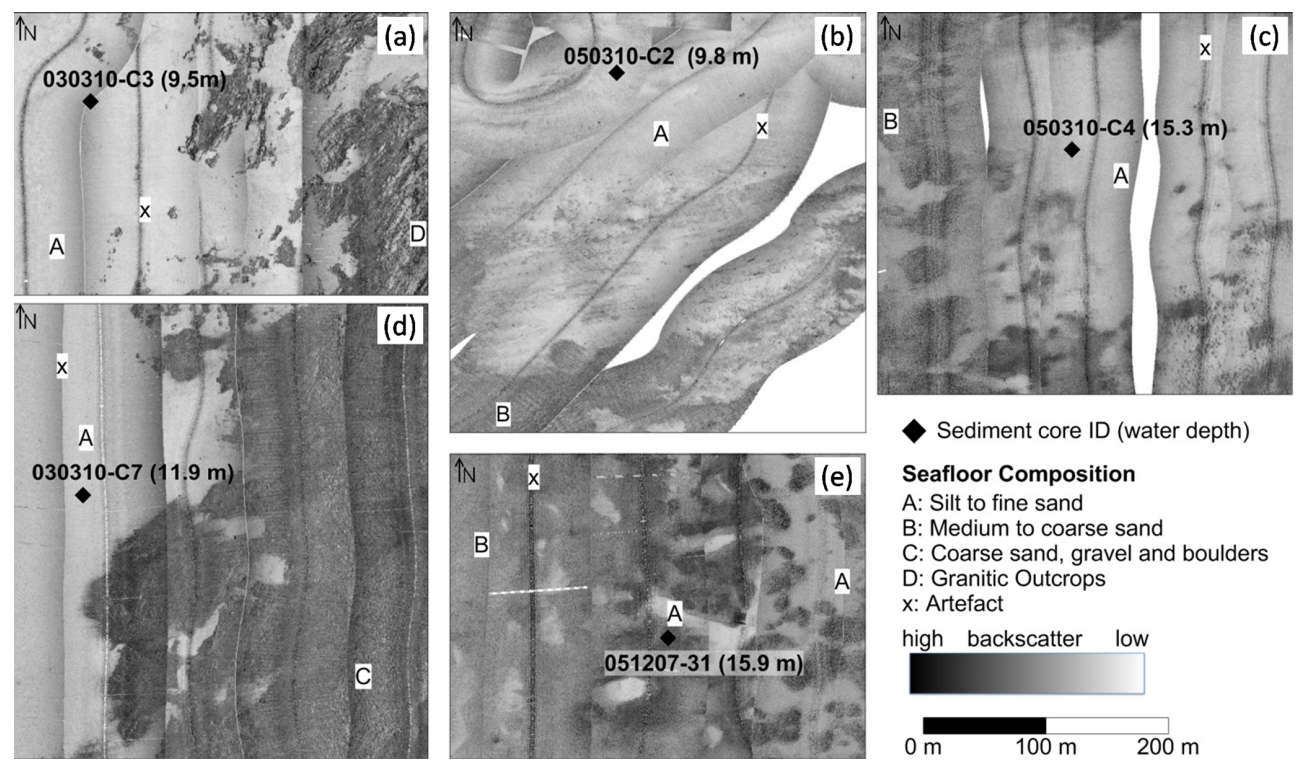

Figure 3. Cutouts of the side-scan sonar mosaic showing the sediment distribution at the coring positions. No data are available for core 030310-C2. The composition of the seafloor was established based on the ground-truthing of the backscatter data with grab samples and underwater video images (Feldens et al., 2012).

sitional boundary, a sand layer rich in shell debris is present between 31 and $29 \mathrm{~cm}$ (facies A, Table 3a-II). No bioturbation traces are observed within this layer. Above a sharp contact at $29 \mathrm{~cm}$, laminated mud is deposited up to $26 \mathrm{~cm}$ (facies B, Table 3a-I). Here, a sand layer $2 \mathrm{~cm}$ in thickness is observed above an erosional contact (facies A, Table 3a-I). Its upper sharp contact at $24 \mathrm{~cm}$ is ripple-shaped. Above the contact at $24 \mathrm{~cm}$, laminated material extends up to ca. $6 \mathrm{~cm}$ (facies E). Single bioturbation traces are observed between 17 and $16 \mathrm{~cm}$ core depth. In this interval, no lamination is recognized. Apparently, the deformed features in the upper $13 \mathrm{~cm}$ of the core are related to disturbances during coring. A highly irregular boundary from ca. 8 to $6 \mathrm{~cm}$ separates the laminated material from more homogeneous sediment that includes few coarser sand grains. Above a sharp boundary at $1 \mathrm{~cm}$, homogeneous fine-grained material is observed.

\subsubsection{Core 030310-C2 (Fig. 2)}

Core 030310-C2, with a length of $23 \mathrm{~cm}$, was retrieved from a silty seafloor at $11.5 \mathrm{~m}$ water depth, $3.3 \mathrm{~km}$ offshore the navigational entrance to Thap Lamu harbor (Fig. 1). Due to strong fishing activities with fixed nets, no side-scan sonar surveys could be carried out here.

From the base of this core to $17 \mathrm{~cm}$, bioturbated fine sand is observed. Few shells are scattered throughout the layer which is assigned to facies E. A $4 \mathrm{~cm}$ thick layer composed of coarse sand and gravel - including shells, laterite fragments and coral debris, which are all typical indicators for facies A - is separated from the fine sand layer below (facies A, Table $3 \mathrm{~b}-\mathrm{II})$. Above an erosional boundary at $13 \mathrm{~cm}$, an $8.5 \mathrm{~cm}$ thick layer of muddy fine sand including few shell fragments is observed (facies B, Table 3b-I). A sharp boundary with an irregular shape - interpreted as a load clast - appears at $4.5 \mathrm{~cm}$. At the top of the core, homogeneous silt to fine sand with frequent traces of bioturbation is present (facies E).

\subsubsection{Core 050310-C4 (Fig. 2)}

Core 050310-C4, with a length of $55 \mathrm{~cm}$, was retrieved $6.3 \mathrm{~km}$ offshore at a water depth of $15.3 \mathrm{~m}$. The position is located within a patch of silt to fine sand that is surrounded by patches of medium to coarse sand (see Fig. 3c).

The lowermost part of the core $(55-51.5 \mathrm{~cm})$ consists of silty to sandy sediment with traces of bioturbation included. At $51.5 \mathrm{~cm}$, a layer of coarse sand, $3 \mathrm{~cm}$ in thickness, is separated from the sediment above and beneath by sharp erosional contacts. The layer appears massive and small shells are observed (facies C, Table 3c-IV). A layer composed of silty sediment is deposited above $48.5 \mathrm{~cm}$. This layer is characterized by the occurrence of few shells and frequent bioturbation traces (facies E). At $37.5 \mathrm{~cm}$, a sharp contact separates a $3 \mathrm{~cm}$ thick layer of laminated fine-grained sediment (facies C, Table 3c-III). The single laminae could not be sampled individually due to their small thickness of 1 to $5 \mathrm{~mm}$. Above, a $6 \mathrm{~cm}$ thick layer of fine sediment is separated by upper and lower sharp contacts, the latter with ripple shapes (facies D). Few shells are present in the layer as well. At $28.5 \mathrm{~cm}$, a sharp but irregular contact - interpreted as load cast - separates coarse sediment (facies B, Table 3C-II). At $24 \mathrm{~cm}$, an erosional contact separates a $7 \mathrm{~cm}$ thick admixture layer of sand, gravel, laterites and shells (facies A, Table 3c- 
Table 3. Characteristics of the sedimentary deposit in shallow water and their event interpretation.

\begin{tabular}{|c|c|c|c|c|c|c|}
\hline Core No. & Photo & X-ray image & $\begin{array}{l}\text { Section } \\
\text { depth } \\
\text { (cm) }\end{array}$ & $\begin{array}{l}\text { Type of } \\
\text { sedimentary } \\
\text { contact }\end{array}$ & $\begin{array}{l}\text { Sediment } \\
\text { description }\end{array}$ & Identified event \\
\hline $\left.\begin{array}{rr}030310-C 3 \\
(a-I) & \frac{\varepsilon}{0} \\
\text { L }\end{array}\right]$ & & & $23-28$ & $\begin{array}{l}\text { upper: sharp } \\
\text { lower: erosional }\end{array}$ & $\begin{array}{l}\text { Top: a } 2 \mathrm{~cm} \text { thick } \\
\text { layer of shell debris } \\
\text { sand } \\
\text { Bottom: laminated } \\
\text { mud }\end{array}$ & $\begin{array}{l}\text { Tsunami (2004) } \\
\text { Top: facies A } \\
\text { Bottom: facies B }\end{array}$ \\
\hline$(\mathrm{a}-\mathrm{II}) \quad \stackrel{\underline{0}}{0}$ & & & $27-37$ & $\begin{array}{l}\text { upper: sharp } \\
\text { lower: erosional }\end{array}$ & $\begin{array}{l}\text { Top: a } 2 \mathrm{~cm} \text { thick } \\
\text { layer of shell debris } \\
\text { sand } \\
\text { Bottom: laminated } \\
\text { mud with mud } \\
\text { clasts }\end{array}$ & $\begin{array}{l}\text { Tsunami (2004) } \\
\text { Top: facies A } \\
\text { Bottom: facies B }\end{array}$ \\
\hline (a-III) $\stackrel{\text { 텅 }}{\circ}$ & & & $47-57$ & $\begin{array}{l}\text { upper: erosional } \\
\text { lower: erosional }\end{array}$ & $\begin{array}{l}\text { Massive sand layer } \\
\text { with clear cross } \\
\text { lamination that is } \\
\text { observed in the } \\
\text { upper five } \\
\text { centimetres }\end{array}$ & Storm \\
\hline & & & $66-71$ & $\begin{array}{l}\text { upper: transitional } \\
\text { (due to smearing) } \\
\text { lower: sharp }\end{array}$ & Massive sand layer & Storm \\
\hline & & & $78-83$ & $\begin{array}{l}\text { upper: sharp } \\
\text { lower: erosional }\end{array}$ & $\begin{array}{l}\text { Massive sand layer } \\
\text { including few shells }\end{array}$ & Storm \\
\hline$(\mathrm{a}-\mathrm{VI}) \stackrel{\varepsilon}{\mathrm{c}}$ & & & $85-95$ & lower: erosional & $\begin{array}{l}\text { Fining upward } \\
\text { sequence } \\
\text { laminated mud with } \\
\text { no bioturbation }\end{array}$ & $\begin{array}{l}\text { Flash flood } \\
\text { (monsoon) }\end{array}$ \\
\hline 030310-C2 & & & $3-13$ & upper: sharp & $\begin{array}{l}\text { Homogenous fine } \\
\text { sand }\end{array}$ & $\begin{array}{l}\text { Tsunami facies B } \\
(2004)\end{array}$ \\
\hline$(b-1)$ 의 & & 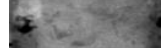 & & & & \\
\hline
\end{tabular}

II). Laminated sediment is found again from 17 to $15 \mathrm{~cm}$. Following a sharp boundary, coarse sediment including minor components of shells is deposited above $15 \mathrm{~cm}$ (facies B, Table 3c-I). Due to disturbances during sampling in the field, the upper boundary of the layer is not clearly visible. However, based on the abundance of shells, it is likely situated at ca. $2 \mathrm{~cm}$. The upper $2 \mathrm{~cm}$ of the core comprises fine-grained sediment with few bioturbation traces (facies E).

\subsubsection{Core 030310-C7 (Fig. 2)}

Core 030310-C7, with a length of $65 \mathrm{~cm}$, was retrieved from a water depth of $11.9 \mathrm{~m}, 2.9 \mathrm{~km}$ offshore (ca. $4.9 \mathrm{~km}$ south of PC), in an area where the seafloor is composed of silty to fine sediment. The boundary between silt- and fine-sand-covered seafloor and coarse sand, gravel and boulders is situated ca. $70 \mathrm{~m}$ to the southeast. Granitic outcrops appear ca. $500 \mathrm{~m}$ to the east (see Fig. 3d).

At the base of the core, laminated material is fining upward from 65 to $61 \mathrm{~cm}$. At $61 \mathrm{~cm}$, a sharp contact with a $6 \mathrm{~cm}$ thick layer composed of coarse sand and occasional 
Table 3.

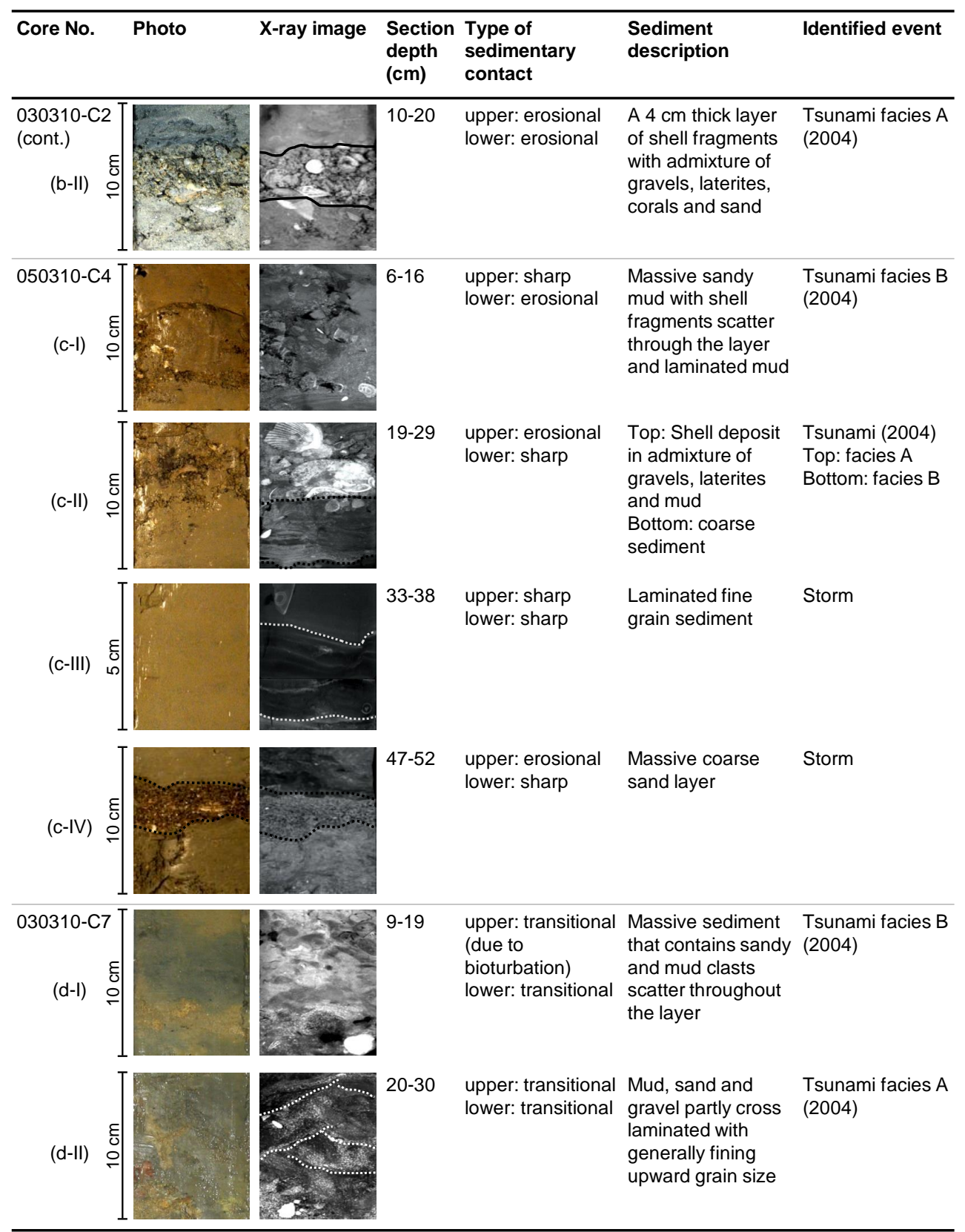

gravel exists (facies C, Table $3 \mathrm{~d}-\mathrm{VI}$ ). This layer is not massive, and no clear fining-upward or -downward trend can be recognized. The layer is draped by a centimeter-thick unit of muddy material on its top. Cross-laminations of coarser sediment are identified from light scattering in X-ray images at 54 and $53 \mathrm{~cm}$ (facies D, Table $3 \mathrm{~d}-\mathrm{V}$ ). A sharp contact has been found at $53 \mathrm{~cm}$ that separates a $6 \mathrm{~cm}$ thick finingupward sequence of laminated fine-grained material, which shows no sign of bioturbation traces (facies D, Table 3d-V). At $47 \mathrm{~cm}$, an irregular sharp contact separates the laminated sediment from a layer of sand, in which faint indications of cross-laminations are observed (facies C, Table 3d-IV). At the top of the sand layer at $42.5 \mathrm{~cm}$, ripple structures draped by a $0.5 \mathrm{~cm}$ thick layer of mud are preserved. Between 42 and $39 \mathrm{~cm}$, a mixture of sand and mud clasts prevails (facies B, Table 3d-III). Above a sharp contact at $39 \mathrm{~cm}$, a $4 \mathrm{~cm}$ thick layer comprising coarse sand and pebbles exists (facies A). A transitional contact at $35 \mathrm{~cm}$ separates sand layer from a $1 \mathrm{~cm}$ thick layer of slightly laminated silty fine sediment (facies B, Table 3d-III). A fining-upward sequence of coarse 
Table 3.

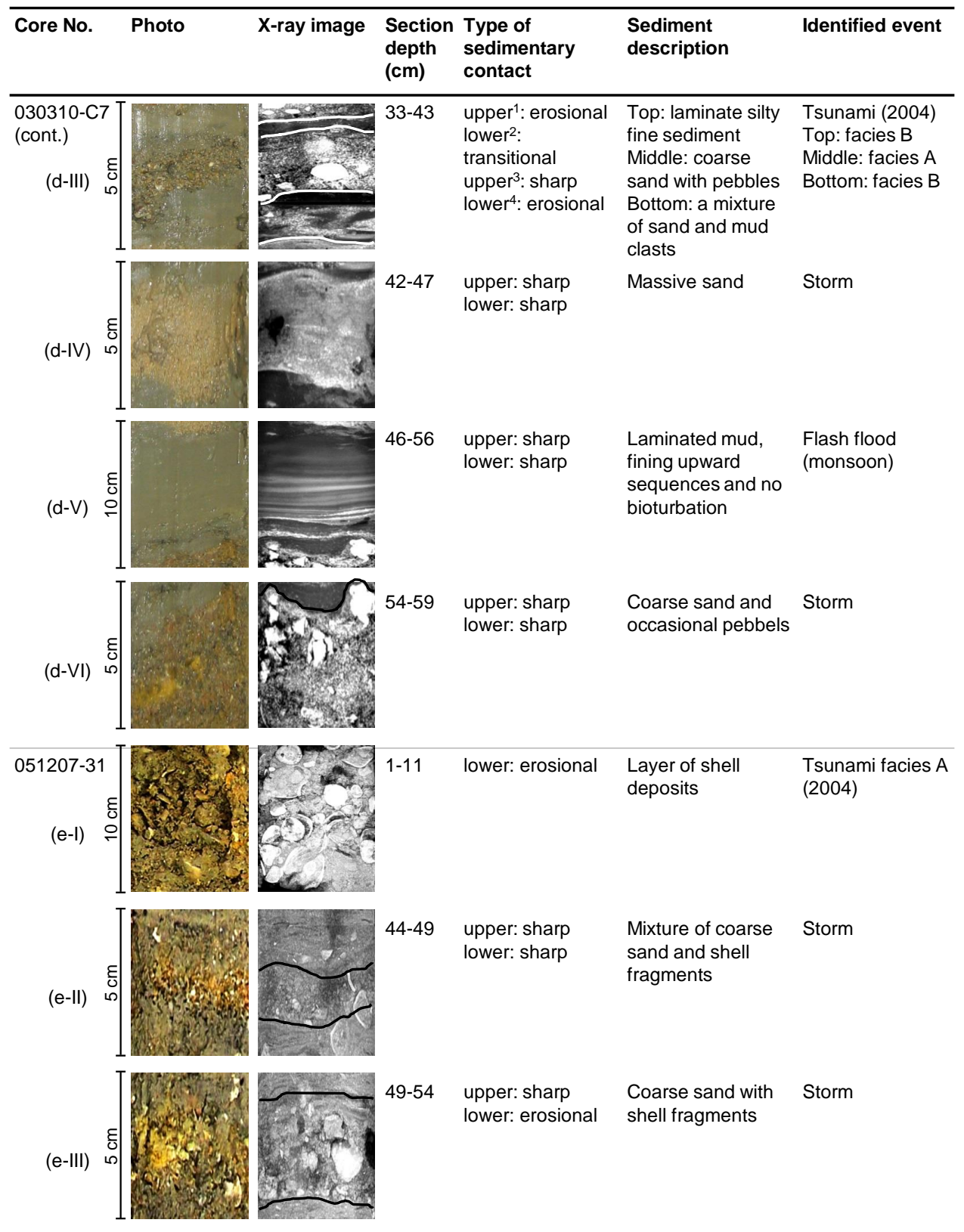

sand, partly pebble-size corals and pebbles exists from 34 to $28 \mathrm{~cm}$ (facies A, Table 3d-II). Above $28 \mathrm{~cm}$, an $8 \mathrm{~cm}$ thick sequence of cross-laminated bedforms is observed with several corals and shells scattered throughout (facies A, Table 3dII). Up to $19 \mathrm{~cm}$, the layer is covered by sand. Above $19 \mathrm{~cm}$, a layer of mixed clasts composed of sand and mud exists, with few shells scattered throughout (facies B, Table 3d-I). Few bioturbation traces are observed at the top $3 \mathrm{~cm}$ of the layer (facies E).

\subsubsection{Core 051207-31 (Fig. 2)}

Core 051207-31, with a length of $70 \mathrm{~cm}$, was retrieved $7.2 \mathrm{~km}$ offshore at a water depth of $15.9 \mathrm{~m}$ at a boundary of patches that are composed of silt to fine sand and partly coarse sand (Fig. 3e). From sub-bottom profiler data it is known that this position is located in a partly filled incised channel system (Feldens et al., 2012).

At the core base, laminated fine-grained material exists from 70 to $68 \mathrm{~cm}$ (facies D, Table $3 \mathrm{e}-\mathrm{V}$ ). A transitional boundary separates a $2 \mathrm{~cm}$ thick layer of massive coarse 
Table 3.

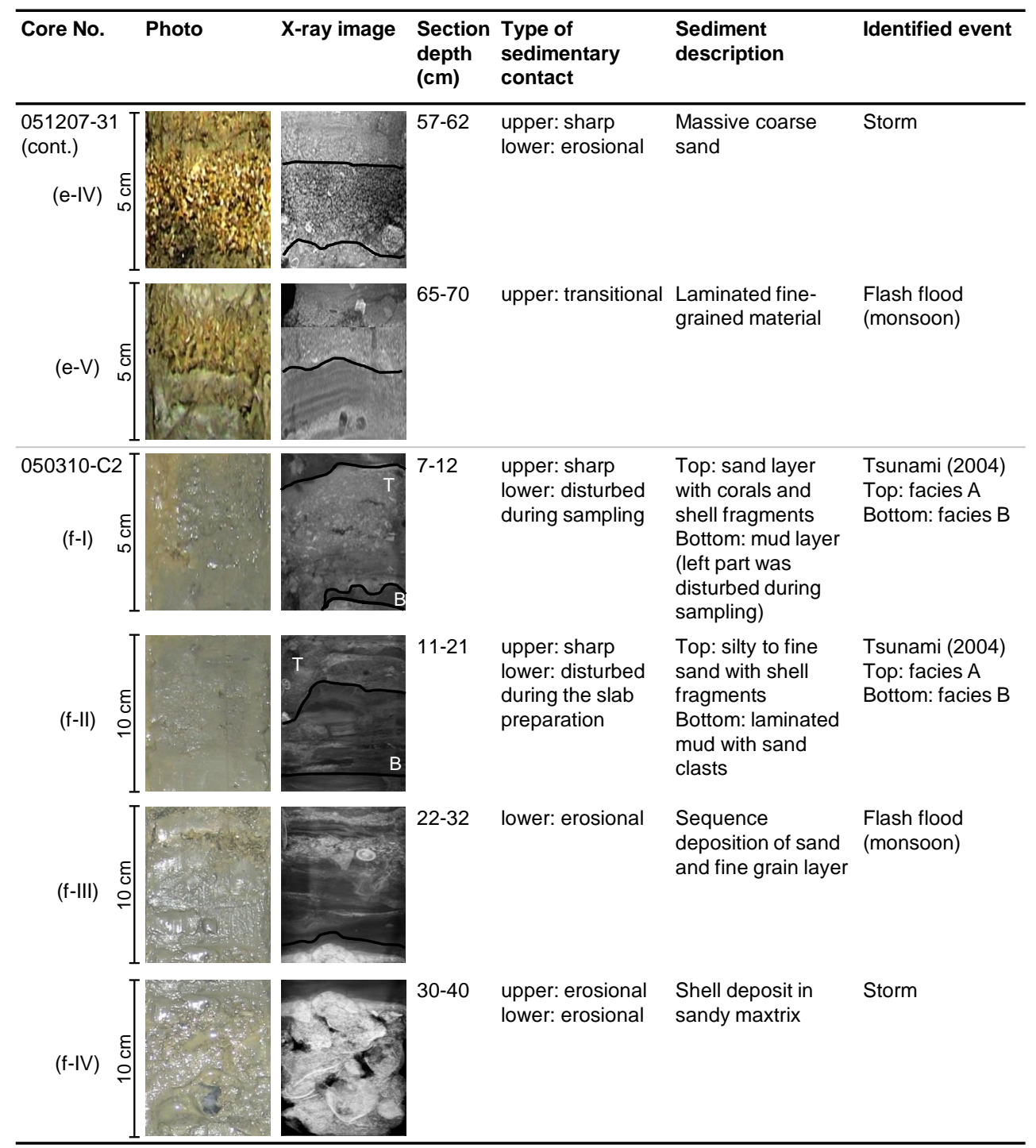

grains extending from 68 to $66 \mathrm{~cm}$. With transitional lower and upper boundaries, the sediment, mainly composed of muddy sand with few shells incorporated, is fining upwards between 66 and $64 \mathrm{~cm}$. Sediment changes into a $2.5 \mathrm{~cm}$ thick layer of massive coarse sand at approximately $61 \mathrm{~cm}$ (facies $\mathrm{C}$, Table $3 \mathrm{e}-\mathrm{IV}$ ). Above $58.5 \mathrm{~cm}$, the sediment is gradually fining upward. At $53 \mathrm{~cm}$, an erosive contact separates the fining-upward sequence from a $3 \mathrm{~cm}$ thick layer comprising pebbles, coarse sand and shell fragments (facies $\mathrm{C}$, Table $3 \mathrm{e}-$ III). Laminated material is present above, up to $47 \mathrm{~cm}$. Few shells are located within this layer. Following a sharp contact at $47 \mathrm{~cm}$, a coarse, fining-upward sequence is present, capped by a sharp boundary at $45 \mathrm{~cm}$ (facies C, Table 3e-II). Finingupward sequences with a sharp boundary composed of pebbles, coarse sand and shell fragments exist within 41-38, 38-
$34.5,34.5-32,32-25,25-20,20-15.5$ and $15.5-11.5 \mathrm{~cm}$. All these units are assigned to facies E. At $11.5 \mathrm{~cm}$, an erosional contact separates a fining-upward sequence from a layer of shells that forms the upper part of this core (facies A, Table $3 \mathrm{e}-\mathrm{I})$.

\subsubsection{Core 050310-C2 (Fig. 2)}

Core 050310-C2, with a length of $75 \mathrm{~cm}$, was collected at a water depth of $9.8 \mathrm{~m}$, located $1.5 \mathrm{~km}$ northeast of PC. The seafloor at the sampling position is composed of silt to fine sand (Fig. 3b).

The lower part of the core from 75 to $40 \mathrm{~cm}$ comprises a silty matrix with few corals and abundant shells scattered throughout. A bioturbation trace is found from 63 to $60 \mathrm{~cm}$. The whole unit belongs to facies E. Above an erosional con- 
tact at $40 \mathrm{~cm}$, a $9 \mathrm{~cm}$ thick layer, mainly composed of large shells in a sandy matrix, is observed (facies C, Table 3f-IV). Above an erosional boundary at $31 \mathrm{~cm}$, laminated mud is observed. Between a sharp upper and lower contact, a sand layer in which shells are present extends from 25 to $24 \mathrm{~cm}$. The sand layer is draped by a $1 \mathrm{~cm}$ thick layer of fine-grained, laminated sediment. A similar sequence is observed above: a $1 \mathrm{~cm}$ thick layer of sand (23 to $22 \mathrm{~cm}$ ) with a sharp upper and lower boundary is draped by laminated muddy material that reaches up to $\sim 20 \mathrm{~cm}$ (facies D, Table $3 \mathrm{f}-\mathrm{III}$ ). The depth of the upper boundary is an approximation, because the sediment was disturbed during the slab preparation. From 20 to $14 \mathrm{~cm}$, several centimeters-thick clasts composed of sandy material disrupt the laminations (facies B, Table $3 \mathrm{f}-\mathrm{II}$ ). Above a sharp contact at $14 \mathrm{~cm}$, a $2 \mathrm{~cm}$ thick sequence of likely silty to fine sand material including shell fragments exists (facies A, Table $3 \mathrm{f}-\mathrm{II}$ ). At $12 \mathrm{~cm}$, a $0.5 \mathrm{~cm}$ thick homogenous mud layer is draped on the layer beneath (facies B, Table 3f-I). However, it is difficult to determine whether this layer extends along the whole core width, as the left part of the core was disturbed during sampling. Above, a coarser sand layer with a sharp upper contact is deposited from 11.5 to $7.5 \mathrm{~cm}$, which includes pieces of corals and shell fragments (facies A, Table 3f-I). The top of the core (above $7.5 \mathrm{~cm}$ core depth) was partly disturbed during sampling, but it apparently consists of bioturbated but otherwise homogeneous fine-grained material, with the exception of few sandy clasts with a diameter of $1-5 \mathrm{~mm}$ (facies $\mathrm{E}$ ).

\section{Summary of core description}

While the cores appear highly diverse, in general, five different facies are recognized within the presented cores, which are termed facies A to E. In several cores, several centimeterthick layers comprised of shells and shell debris with variable fraction of coarse sand and gravel exist. These are assigned to tsunami deposits, named facies A. Poorly sorted sediment units comprising mud to sand and including mud and sand clasts are found, assigned as well to tsunami deposits, facies B.

Sand layers that are partly massive and partly show slight lamination occur. Shells are scattered throughout the sand layers. At the top, rippled shapes draped with mud are partly preserved. These structures are related to storm deposits, named facies $\mathrm{C}$.

Most frequently occurring are layers composed of mainly clayey silt with few sand layers, which are commonly laminated and generally fining upward with transitional boundaries (individual laminae could not be sampled). Bioturbation is rarely observed in this facies, named facies $\mathrm{D}$, representing partly reworked flash-flood deposits.

All other layers, which could not be assigned to event deposits, are regular shelf deposits, assigned to facies E. Depending on their location, these layers are composed of sandy to muddy sediment, containing fragments of corals and

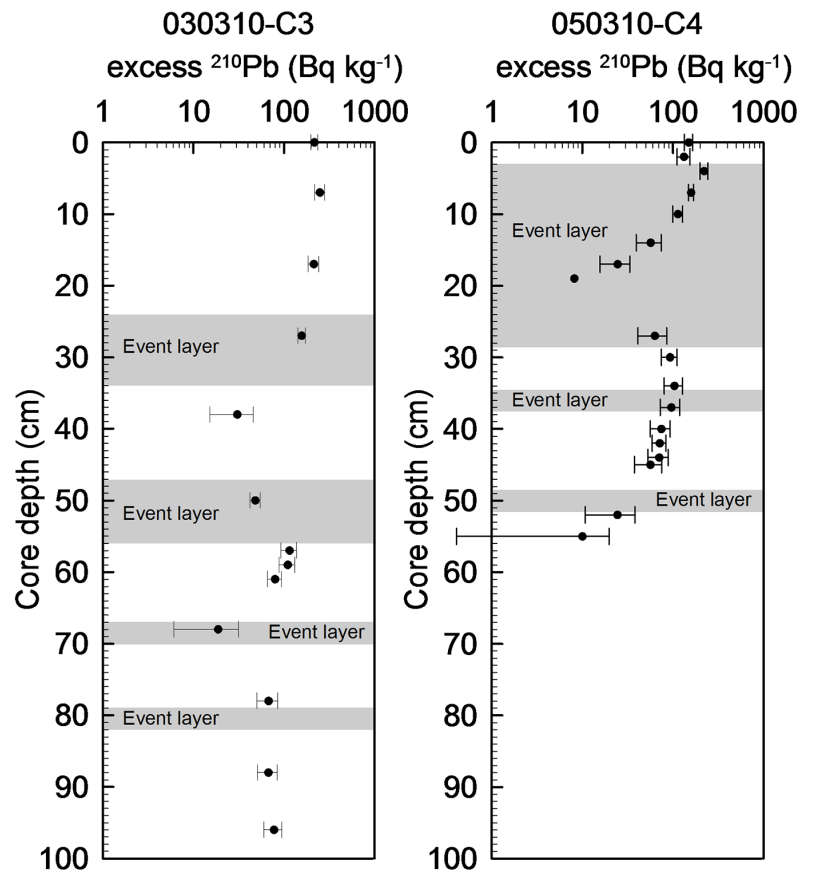

Figure 4. Excess ${ }^{210} \mathrm{~Pb}$ activity profiles with $2 \sigma$ uncertainty ranges observed in the shallow water cores 030310-C3 and 050310-C4.

shells, and show bioturbation. Transitional and sharp contacts to layers above and below are common.

\subsection{Ti / Ca ratios and ${ }^{210} \mathrm{~Pb}$ activity}

The $\mathrm{Ti} / \mathrm{Ca} \log$ ratios displayed in Fig. 2 in all six cores are stable ( $\mathrm{Ti} / \mathrm{Ca}$ log ratios are about -1.6 to -1.1 ) throughout finer sediments (facies B and D), while coarse sediment layers (Facies A, C, E) show Ti / Ca log ratios varying between -2.8 and -0.1 .

The excess ${ }^{210} \mathrm{~Pb}$ activity profiles measured in core 030310-C3 and 050310-C4 (Fig. 4) reveal a decline of activity downcore with several anomalies, the latter being interpreted as event layers. Given an unsteady sedimentation, the presence of event layers and the lack of an independent age control, which is required for ${ }^{210} \mathrm{~Pb}$ dating (Smith, 2001), absolute dates cannot be given for particular core sections. However, the presence of excess ${ }^{210} \mathrm{~Pb}$ confirms - assuming supported ${ }^{210} \mathrm{~Pb}$ similar to values measured in coarse-grained event layers - that the sampled sediments have been deposited over the last century. Precise calculation of sediment accumulation rates are not possible as the accumulation is not steady, based on the interpretation of X-Ray images, and uniform conditions were not encountered in the lowermost part of the core; the given values only represent rough estimations. However, some important indications may be drawn from the measured ${ }^{210} \mathrm{~Pb}$ activity profiles. The estimated average accumulation rate for the upper $27 \mathrm{~cm}$ of core 030310-C3 (Fig. 4) is 
about $2.6 \mathrm{~cm} \mathrm{y}^{-1}$ when considering a mixing surface layer of $\sim 7 \mathrm{~cm}$ and using the surficial sediment for reference activity. The upper segment $(0-28 \mathrm{~cm})$ of the activity profile of core 050310-C4 (Fig. 4) shows a general decrease in the excess ${ }^{210} \mathrm{~Pb}$ activity, which correlates with an increase in sand content. Using the surficial sediment for reference activity, an accumulation rate of $0.5 \mathrm{~cm} \mathrm{y}^{-1}$ may be assumed for the uppermost centimeters of the sediment above the first event layer. Below $37 \mathrm{~cm}$, the profile approaches supported ${ }^{210} \mathrm{~Pb}$ activity as observed in the coarse-grained event layers.

\section{Discussion}

\subsection{Identification of event deposits}

The analyzed core data allow differentiating between three types of event deposits, which are related to (1) flash floods, (2) storms and typhoons and (3) the 2004 Indian Ocean Tsunami.

The majority of the laminated fine-grained sediments of facies D (Figs. 2, 5 and Table 3) are interpreted as reworked flash-flood deposits which have not been described from the Andaman Sea yet. In general, the most important source from which fine sediment is supplied to accumulate on continental shelves is river discharge (Kuehl et al., 1985; Wright and Nittrouer, 1995; Geyer et al., 2004; Crokett and Nittrouer, 2004; Palinkas et al., 2006), which is minor in the investigation area (Jankaew et al., 2008; Feldens et al., 2009; Brill et al., 2011). However, anthropogenic activities that have been increasing during the last century - such as tin mining on and offshore, construction of tourist resorts, deforestation, agriculture and urbanization - all cause river discharge due to increased exposure to weathering and erosion of fine-grained sediment (Wolanski and Spagnol, 2000). In the course of flash floods during the southwest monsoon (rainy season), these fine sediments are subsequently transported through ephemeral channels towards the sea (e.g., Curran et al., 2002; Mulder et al., 2003; Malmon et al., 2004; Owens, 2005; Hill et al., 2007). Enhanced sedimentation due to anthropogenic impacts has been observed in different settings such as tropical estuaries in Papua New Guinea, Vietnam, Australia and Indonesia (Wolanski and Spagnol, 2000); the Pearl River in Hong Kong (Owen and Lee, 2004; Owen, 2005); and the Waiapu River in New Zealand (Wadman and McNinch, 2008). Offshore Khao Lak, Feldens et al. (2012) found sediment distributions composed of silt and fine sand deposited above $15 \mathrm{~m}$ water depth that were orientated parallel to the shoreline. These fine sediments offshore Khao Lak, which show little cohesiveness due to a high percentage of coarse silt and fine sand, were deposited during a multitude of smallscale events (Table 3a-V, 3c-IV, 3d-V and 3e-VI and Fig. 5). In the X-ray images, they are recognized as laminated sections of mud, silt and fine sand. Regular reworking and redeposition from suspension are indicated by the frequent oc-

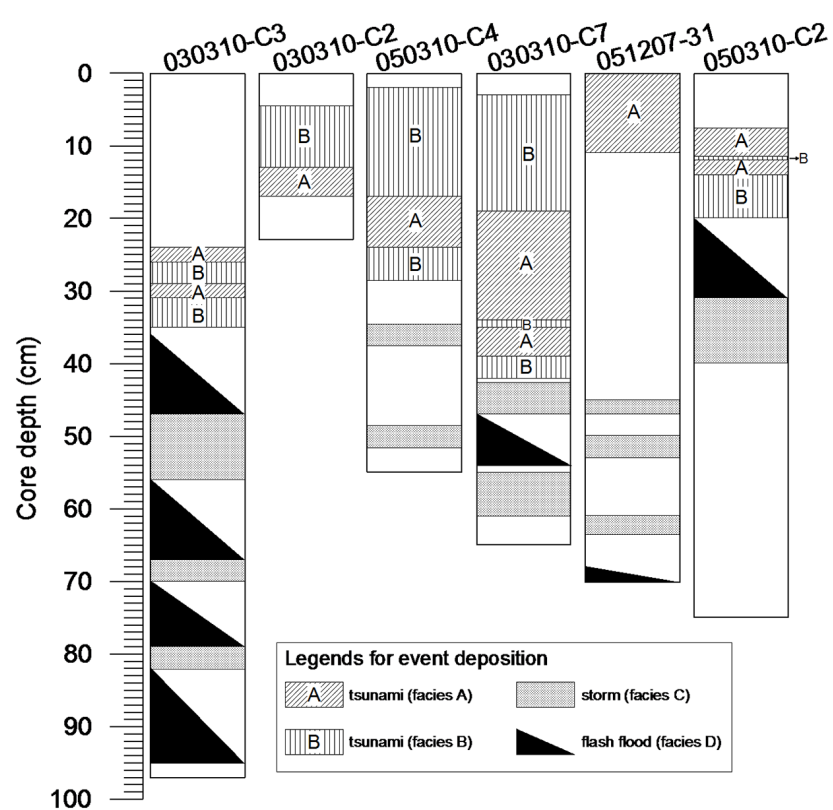

Figure 5. Event sequence log diagram for sediment cores taken in shallow water $(<15 \mathrm{~m}$ water depth).

currence of fining-upward sequences, showing a distinct absence of bioturbation. This indicates episodically high accumulation rates (Wheatcroft and Drake, 2003), supported by the tsunami layers buried to depths $>20 \mathrm{~cm}$ in some cores (this study; Sakuna et al., 2012). Notable is the frequent occurrence of thin sand layers less than $1 \mathrm{~cm}$ in thickness with sharp upper and lower boundaries within the laminated core sections in core 051207-31. Based on side-scan sonar images, this core is situated close to a boundary of fine and coarse sediment (Fig. 3), which explains the transport of sand into areas covered by finer sediment in the range of annual cycles without exceptional storm events, as demonstrated by repeated side-scan sonar mapping offshore Khao Lak (Feldens et al., 2012).

In the sedimentary record, ideal proximal tempestites comprise an erosional lower contact, a graded or massive lower section, cross-stratification and plane laminations, and they frequently have ripple structures at their top (e.g., Einsele et al., 1991; Krassay, 1994; Weidong et al., 1997; Allison, 2005). Layers showing parts of these characteristics comprise facies $\mathrm{C}$ and are frequently observed in the $\mathrm{X}$-ray images (Table 3a-II, 3a-III, 3a-IV, 3c-IV, 3d-IV, 3d-VII and 3e-III and Fig. 5), including sharp and partly erosional lower contacts, preserved cross-laminations, ripples and gradedbedded sand without mud content. Based on measurable ${ }^{210} \mathrm{~Pb}$ activity throughout the core, several proposed event deposits in the cores 030310-C3 and 050310-C4 are less than 100 years old but are older than the 2004 Indian Ocean Tsunami, even when accounting for intermittent sedimentation. During the 52-year period from 1945 to 1996, only nine tropical storms passed through the investigation area 
(Brand, 2009; see Table 1). Therefore, it is very likely that these storms are responsible for the deposition of facies C. It should be noted that more storms than event layers occurred during the period documented, although the lower parts of the sediment cores may be expected to reach back to 1945 based on measurable excess ${ }^{210} \mathrm{~Pb}$ activities of fine-grained sediment in the lower core sections (Fig. 4). This can be explained either by storms not leaving traces at the coring sites or, considering low accumulation between individual storm events, by the erosion and reworking of older event deposits.

Several event layers attributed to facies A and B in the uppermost part of the cores (Table 4 and Fig. 5) show different characteristics from the event layers beneath, which are attributed to storm events. They display a larger variability, ranging from $10 \mathrm{~cm}$ thick shell deposits to mud deposits including coarse sand grains, laterites and shell debris as well as clasts of various compositions. The different depth beneath the seafloor of these events layers may be due to expected small-scale changes in sediment accumulation rates (also indicated by excess ${ }^{210} \mathrm{~Pb}$ ) across the shelf. Based on the accumulation rates estimated for core 030310-C 3 and 050310-C4, the age of these deposits is 9 and 4 years, respectively. Despite the large uncertainties in ${ }^{210} \mathrm{~Pb}$ dating at this location, the absence of large storms between the tsunami and our sampling in 2010 and the partly different sedimentary characteristics observed in X-ray images suggest that the uppermost event layer in these cores is the result of the 2004 Indian Ocean Tsunami.

\subsection{Identification and features of the tsunami facies}

Event deposits attributed to the 2004 Indian Ocean Tsunami based on ${ }^{210} \mathrm{~Pb}$ dating are grouped into facies A and $\mathrm{B}$ (Table 4 and Fig. 5), representing the variable characteristics of offshore tsunami deposits.

Except in core 030310-C3, the inferred tsunami deposit sequences show sand enriched with shells or shell debris (facies A) at their base. Seafloor dominated by shells, coral rubble and sand is frequent between 15 to $20 \mathrm{~m}$ water depth offshore Khao Lak (Feldens et al., 2012). Therefore, this layer is likely to be eroded during the propagation of tsunami waves from the open ocean to shallow waters. Considering a change of grain size, a marine origin of these deposits may eventually be indicated by generally lower $\mathrm{Ti} / \mathrm{Ca}$ ratios in the massive sand layer (facies A) compared to the surrounding muddy layers (Fig. 2). Despite promising first results (Sakuna et al., 2012), Ti / Ca ratios appear unsuited to identify offshore tsunami deposits in a shallow-water setting, where tsunami deposits mainly comprise marine sands or backwash material, which is an admixture of marine and terrigenous material, and considering that several wave trains hit the coastline. However, foraminifera transfer functions further support a transport of facies A material from these water depths (Milker et al., 2013). A depth of ca. $20 \mathrm{~m}$ is substantially lower compared to the depths found during pre- vious studies of tsunami impact based on wave theory and the analysis of microfossils (e.g., Nanayama and Shigeno, 2006; Weiss and Bahlburg, 2006; Weiss, 2008; Uchida et al., 2010). It is unknown whether the local shelf morphology offshore Khao Lak prohibited the substantial erosion of material from deeper waters or whether the sediments transported onshore from deeper waters were not preserved. As no storm event occurred between the 2004 tsunami and the time of sampling, the latter appears unlikely, suggesting that the preserved tsunami deposits offshore Khao Lak are in fact limited to shallow water depths. However, it cannot be ruled out that tsunami deposits exist beneath the shelf break, but no samples are available from that area. Further, facies A in core $050310-\mathrm{C} 2$ is located in a core depth of $30 \mathrm{~cm}$ and is covered by a fining-upward sequence. Therefore, it is likely that it was deposited by a storm event and would have similar sedimentary characteristics to parts of the more clearly identifiable tsunami deposits. This indicates that tsunami run-up deposits may be hard to distinguish from tempestites in sediment cores, even a few years after a tsunami event.

Sediments from facies A are mostly covered by massive deposits commonly including mud and/or sand clasts (facies B). Those clasts are widely used as a sedimentological proxy to identify tsunami deposits and are interpreted as relating to hyperpycnal tsunami backwash flows (Goff et al., 2004; Le Roux and Vargas, 2005; Morton et al., 2007; Goodman-Tchernov et al., 2009; Sakuna et al., 2012). Clasts are found in the uppermost part of the tsunami sequence and include material transported during the backwash, as shown by foraminifera composition (Milker et al., 2013) and the presence of laterites and grass (Feldens et al., 2012; Sakuna et al., 2012). The Ti / Ca ratios in this facies type are not noticeably different from the inferred flash floods deposits, which have to originate from onshore sediment as well (Fig. 2). An inverted sequence in core 030310-C3 may be explained by three wave trains approaching the coastline, causing several cycles of onshore-offshore transport directions. However, clasts are not observed within all the cores. The absence of backwash deposits in core 051207-31 may be related to subsequent erosion, with the tsunami deposits exposed at the seafloor.

Intensive cross-lamination in a layer sandwiched between the tsunami facies A and B is observed within core 030310C7. It may be assumed that the cross-bedding is related to multiple flow reversals between the run-up and backwash of the three wave trains approaching the coastline during the 2004 tsunami event (e.g., Siripong, 2006). Cross-bedding is a common feature for onshore tsunami deposits, where it was widely used to indicate the hydrodynamic regime during the deposition (Dawson et al., 1996; Nanayama et al., 2000; Goff et al., 2001; Bahlburg and Weiss, 2007; Engel and Brückner, 2011). 
Table 4. Tsunami facies types.

\begin{tabular}{|c|c|c|c|c|}
\hline $\begin{array}{l}\text { Tsunami deposits } \\
\text { facies types }\end{array}$ & X-ray images & Core no. & $\begin{array}{l}\text { Section } \\
\text { depth }(\mathrm{cm})\end{array}$ & Sediment description \\
\hline \multirow[t]{5}{*}{$\begin{array}{l}\text { A: sand enriched } \\
\text { with shells or shell } \\
\text { debris }\end{array}$} & $\begin{array}{l}\varepsilon \\
0 \\
\circ\end{array}$ & 051207-31 & $0-10$ & $\begin{array}{l}\text { A } 10 \mathrm{~cm} \text { thick of shell deposit at the top } \\
\text { of core with a lower erosional contact }\end{array}$ \\
\hline & $\begin{array}{l}\varepsilon \\
0 \\
0\end{array}$ & 030310-C2 & $10-20$ & $\begin{array}{l}\text { A } 4 \mathrm{~cm} \text { thick layer of shell fragments } \\
\text { with admixture of gravels, laterites, } \\
\text { corals and sand }\end{array}$ \\
\hline & $\frac{\varepsilon}{0}$ & 030310-C3 & $29-34$ & $\begin{array}{l}\text { A } 2 \mathrm{~cm} \text { thick layer of shell debris sand } \\
\text { with sharp boundary at the top and } \\
\text { bottom layer }\end{array}$ \\
\hline & & 050310-C4 & $18.5-24$ & $\begin{array}{l}\text { Shell deposit in admixture of gravels, } \\
\text { laterites and mud }\end{array}$ \\
\hline & E્ & 030310-C7 & $20-30$ & $\begin{array}{l}\text { Mud, sand and gravel partly cross } \\
\text { laminated with generally fining upward } \\
\text { grain size }\end{array}$ \\
\hline \multirow[t]{4}{*}{$\begin{array}{l}\text { B: massive layers } \\
\text { common with mud } \\
\text { or sand clasts }\end{array}$} & \begin{tabular}{l|l}
$E$ \\
0 \\
0
\end{tabular} & 030310-C2 & 3-13 & $\begin{array}{l}\text { Homogenous fine sand with an } \\
\text { irregular sharp contact }\end{array}$ \\
\hline & & 030310-C3 & 29-34 & Laminated mud with mud clasts \\
\hline & & 030310-C7 & $2-12$ & $\begin{array}{l}\text { Homogenous mud with several mud } \\
\text { clasts }\end{array}$ \\
\hline & & 050310-C4 & $6-16$ & $\begin{array}{l}\text { Massive mud with shell fragments } \\
\text { scatter through the layer and mud clast }\end{array}$ \\
\hline
\end{tabular}

\subsection{Comparison of tsunami, storm and flash-flood facies}

On the Andaman Sea shelf, the presence of deposits related to tsunami, tropical storms and annual flash floods during the summer monsoon season allows us to compare the sedimentary signatures of these events at the same offshore location. The distinction of tsunami deposits from those deposited by other high-energy events, such as storms or hurricanes, are still problematic, even for deposits on land (Nanayama et al., 2000; Kortekaas and Dawson, 2007; Morton et al., 2007; Switzer and Jones, 2008; Phantuwongraj and Choowong, 2012). Previous studies proved that a series of proxies must be applied, e.g., the geomorphological setting, sedimentary structures, microfossil assemblages and geochemical components (Goff et al., 2004, 2012; Kortekaas and Dawson, 2007; 
Table 5. Differences between the sedimentary features of flash-flood, tsunami and storm deposits on the Andaman Sea shelf.

\begin{tabular}{|c|c|c|c|}
\hline Deposition characteristics & $\begin{array}{l}\text { Flash flood } \\
\text { (monsoon effect) }\end{array}$ & Tsunami & Tropical storm \\
\hline Age of events (AD) & - & 2004 & $\begin{array}{l}1962-1965,1972-1973, \\
1989\end{array}$ \\
\hline $\begin{array}{l}\text { Occurrence (max observed } \\
\text { water depth) }\end{array}$ & $16 \mathrm{~m}$ & $16 \mathrm{~m}$ & $45 \mathrm{~m}$ \\
\hline Deposit thickness & $1-12 \mathrm{~cm}$ & $12-30 \mathrm{~cm}$ & $2-9 \mathrm{~cm}$ \\
\hline Sedimentary contact & transitional & sharp, erosional & sharp, erosional \\
\hline Grain size range & mud & mud to gravels & silt to coarse sand \\
\hline Sediment sorting & $\begin{array}{l}\text { poorly sorted but better } \\
\text { than tsunami deposits }\end{array}$ & poorly sorted & $\begin{array}{l}\text { poorly sorted but better } \\
\text { than tsunami deposits }\end{array}$ \\
\hline Sedimentary structure & $\begin{array}{l}\text { laminated, fining-upward } \\
\text { sequences }\end{array}$ & $\begin{array}{l}\text { laminated, massive } \\
\text { structures, fining-upward } \\
\text { sequence, internal erosional } \\
\text { surfaces }\end{array}$ & $\begin{array}{l}\text { rippled, cross-laminated, } \\
\text { graded sand }\end{array}$ \\
\hline Presence of rip-up clast & no & yes & no \\
\hline Terrigenous component & no & wood and laterites & no \\
\hline Anthropogenic artifact & no & pieces of brick & no \\
\hline $\begin{array}{l}\text { Presence of carbonate } \\
\text { material }\end{array}$ & $\begin{array}{l}\text { occasionally shell } \\
\text { fragments }\end{array}$ & $\begin{array}{l}\text { pieces of broken shells and } \\
\text { corals }\end{array}$ & $\begin{array}{l}\text { complete shells and their } \\
\text { fragments (typical for } \\
\text { beach sand) }\end{array}$ \\
\hline Presence of mud & yes & yes & no \\
\hline Presence of sand & no & yes & yes \\
\hline
\end{tabular}

Morton et al., 2007; Ramírez-Herrera et al., 2012; ChaguéGoff et al., 2011; Richmond et al., 2011, Sakuna et al., 2012). The different signatures of the identified event deposits are summarized in Table 5. In particular, the differentiation between tsunami facies type A and storm deposits appears to be problematic. Storms raise water levels due to their low atmospheric pressure and cause coastal flooding (Ogston et al., 2000; Harris and Heap, 2009). Sediment is kept in suspension and deposited with waning energy levels. This results in deposits of graded sand, frequently showing cross-bedding. Wave ripple marks draped with mud are frequently only preserved at the top of the storm deposit sequence (Weidong et al., 1997). While a tsunami event may comprise several waves, thus allowing the deposition of several mud drapes, it is expected that later waves erode the previously deposited mud drapes. Distinct lamina of shells and their fragments are common in storm deposits, most likely because of highfrequency waves (Morton et al., 2007), and have also been observed in tsunami deposits offshore Khao Lak (this study). Therefore, neither the observed cross-laminated sections nor the presence of sand, rich in shells or shell debris (facies A), are suitable as a proxy to distinguish tsunami and storm deposits. In contrast, mud and sand clasts (facies B) were previously used to discriminate storm and tsunami deposits (e.g., Morton et al., 2007; Phantuwongraj and Choowong, 2012), as were terrestrial components and anthropogenic artifacts. The backwash transports a variety of material from the hinterland towards offshore, and the high-density backwash flows support the formation of clasts (Dawson and Stewart, 2007; Morton et al., 2007; Shanmugam, 2011; RamírezHerrera et al., 2012). In contrast, erosion during storms is focused on the shoreface and the beach (Snedden et al., 1988; Allison et al., 2005); thus, clasts and terrestrial material are expected to appear less frequently within storm deposits. This highlights the importance of material deposited during the tsunami backwash for the identification of past tsunami events. Further proxies using the increased occurrence of terrestrial material for the discrimination of offshore tsunami and storm deposits could be plants, anthropogenic material (for recent events) and geochemical proxies such as polycyclic aromatic hydrocarbon (PAH; Tipmanee et al., 2012) or microfossils (Milker at al., 2013). Tsunami backwash deposits have to be differentiated from flash floods, which can also deposit terrigenous material out of hyperpycnal density flows (Mulder et al., 2003; Bourrin et al., 2008). In fact, little difference exists in the $\mathrm{Ti} / \mathrm{Ca}$ ratios between 
flash-flood and tsunami deposits offshore PC. However, flash floods differ from the identified tsunami deposits sedimentologically: they are generally better sorted than tsunami deposits and include less sand, likely related to the higher energy of the tsunami backwash flow. The higher energy of the backwash flow is further reflected by the generally sharp and erosional boundaries of the backwash deposits, while flashflood deposits show mostly transitional boundaries. Additionally, mud clasts are absent in the observed flash-flood deposits.

\section{Conclusions}

On the Andaman Sea continental shelf, tsunami, storm and flash-flood deposits have been preserved in close vicinity to each other, allowing us to compare their sedimentological characteristics. Flash-flood deposits comprise laminated, fining-upward mud with occasional shell fragments. Large storm or typhoon deposits show typically sharp and partly erosional lower contacts and are composed of rippled, crosslaminated and graded sand without mud. The 2004 Indian Ocean Tsunami left two different sedimentary facies, including (1) sand enriched in shell and shell debris and (2) layers including mud and sand clasts. From this study, the most prominent difference between the storm and tsunami deposits offshore Khao Lak area is the presence of terrestrial components, anthropogenic artifacts and mud in the latter.

Acknowledgements. The authors wish to thank the Phuket Marine Biological Center (PMBC) for supporting us with ship time of RV ChakratongTongyai and RV Boonlert Pasook as well as with other facilities during field campaigns. This study was funded by the Deutsche Forschungsgemeinschaft (DFG) grant SCHW 572/11, the National Research Council of Thailand (NRCT) and the DAAD (Deutscher Akademischer Austauschdienst) fellowship provided to D. Sakuna-Schwartz for a PhD study at Kiel University.

Edited by: H. Sterr

Reviewed by: one anonymous referee

\section{References}

Abrantes, F., Alt-Epping, U., Lebreiro, S., Voelker, A., and Schneider, R.: Sedimentological record of tsunamis on shallow-shelf areas, The case of the $1969 \mathrm{AD}$ and $1755 \mathrm{AD}$ tsunamis on the Portuguese Shelf off Lisbon, Mar. Geol., 249, 283-293, 2008.

Allison, M. A., Sheremet, A., Goñi, M. A., and Stone, G. W.: Storm layer deposition on the Mississippi-Atchafalaya subaqueous delta generated by Hurricane Lili in 2002, Cont. Shelf Res., 25, 2213-2232, 2005.

Bahlburg, H. and Weiss, R.: Sedimentology of the December 26, 2004, Sumatra tsunami deposits in easternIndia (Tamil Nadu) and Kenya, Int. J. Earth Sci., 96, 1195-1209, 2007.
Bahr, A., Lamy, F., Arz, H., Kuhlmann, H., and Wefe, G.: Late glacial to Holocene climate and sedimentation history in the NW Black Sea, Mar. Geol., 214, 309-322, 2005.

Best, A. I. and Gunn, D. E.: Calibration of marine sediment core loggers for quantitative acoustic impedance studies, Mar. Geol., 160, 137-146, 1999.

Blott, S. J. and Pye, K.: Gradistat, a grain-size distribution and statistics package for the analysis of unconsolidated sediments, Earth Surf. Proc. Land., 26, 1237-1248, 2001.

Bourrin, F., Friend, P. L., Amos, C. L., Manca, E., Ulses, C., Palanques, A., Durrieu de Madron, X., and Thompson, C. E. L.: Sediment dispersal from a typical Mediterranean flood, The Têt River, Gulf of Lions, Cont. Shelf Res., 28, 1895-1910, 2008.

Brand, S. (Ed.): Tropical cyclones affecting Phuket, http://www.nrlmry.navy.mil/port_studies/thh-nc/thailand/ phuket/text/frame.htm (last access: 11 June 2015), 2009.

Brill, D., Brückner, H., Jankaew, K., Kelletat, D., Scheffers, A., and Scheffers, S.: Potential predecessors of the 2004 Indian Ocean Tsunami - Sedimentary evidence of extreme wave events at Ban Bang Sak, SW Thailand, Sediment. Geol., 239, 146-161, 2011.

Brill, D., Pint, A., Jankaew, K., Frenzel, P., Schwarzer, K., Vött, A., and Brückner, H.: Sediment transport and hydrodynamic parameters of Tsunami waves recorded in offshore Geoarchives - a case study from Thailand, J. Coastal Res., 30, 922-941, doi:10.2112/JCOASTRES-D-13-00206.1, 2014a.

Brill, D., Jankaew, K., Neubauer, N. P., Kelletat, D., Scheffers, A., Vött, A., and Brückner, H.: Holocene coastal evolution of southwest Thailand - implications for the site-specific preservation of palaeotsunami deposits, Z. Geomorphol., 58, 273-303, doi:10.1127/0372-8854/2014/0132, 2014b.

Chagué-Goff, C., Schneider, J. L., Goff, J. R., Dominey-Howes, D., and Strotz, L.: Expanding the proxy toolkit to help identify past events - Lessons from the 2004 Indian Ocean Tsunami and the 2009 South Pacific Tsunami, Earth-Sci. Rev., 107, 107-122, doi:10.1016/j.earscirev.2011.03.007, 2011.

Chavanich, S., Siripong, A., Sojisuporn, P., and Menasaveta, P.: Impact of tsunami on the seafloor and corals in Thailand, Coral Reefs, 24, 535, doi:10.1007/s00338-005-0016-2, 2005.

Cheng, W. and Weiss, R.: On sediment extent and runup of tsunami waves, Earth Planet. Sc. Lett., 362, 305-309, 2013.

Choowong, M., Murakoshi, N., Hisada, K., Charusiri, P., Daorerk, V., Charoentitirat, T., Chutakositkanon, V., Jankaew, K., and Kanjanapayont, P.: Erosion and deposition by the 2004 Indian Ocean tsunami in Phuket and Pang-nga Provinces, Thailand, J. Coastal Res., 23, 1270-1276, 2007.

Choowong, M., Phantuwongraj, S., Charoentitirat, T., Chutakositkanon, V., Yumuang, S., and Charusiri, P.: Beach recovery after 2004 Indian Ocean tsunami from Phang-nga, Thailand, Geomorphology, 104, 134-142, 2009.

Colin, C., Turpin, L., Bertaux, J., Desprairies, A., and Kissel, C.: Erosional history of the Himalayan and Burman ranges during the last two glacial-interglacial cycles, Earth Planet. Sc. Lett., 171, 647-660, 1999.

Crokett, J. S. and Nittrouer, C. A.: The sandy inner shelf as a repository for muddy sediment, an example from Northern California, Cont. Shelf Res., 24, 55-73, 2004.

Curran, K. J., Hill, P. S., and Milligan, T. G.: Fine-grained suspended sediment dynamics in the Eel River flood plume, Cont. Shelf Res., 22, 2537-2550, 2002. 
Cutter Jr., G. R. and Diaz, R. J.: Biological alteration of physically structured flood deposits on the Eel margin, northern California, Cont. Shelf Res., 20, 235-253, 2000.

Dartnell, P. and Gardner, J. V.: Predicting Seafloor Facies from Multibeam Bathymetry and Backscatter Data, Photogramm. Eng. Rem. S., 70, 1081-1091, 2004.

Dawson, A. G. and Stewart, I.: Tsunami deposits in the geological record, Sediment. Geol., 200, 166-183, 2007.

Dawson, A. G., Shi, S., Dawson, S., Takahashis, T., and Shutos, N.: Coastal sedimentation associated with the June 2nd and 3rd, 1994, tsunami in Rajegwesi, Java, Quaternary Sci. Rev., 15, 901912, 1996

Di Geronimo, I., Choowong, M., and Phantuwongraj, S.: Geomorphology and Superficial Bottom Sediments of KhaoLak Coastal Area (SW Thailand), Pol. J. Environ. Stud., 18, 111-121, 2009.

Einsele, G., Ricken, W., and Seilacher, A. (Eds.): Cycles and events in stratigraphy, Springer-Verlag, Berlin, Heidelberg, New York, 955 pp., 1991.

Engel, M. and Brückner, H.: The identification of palaeo-tsunami deposits - a major challenge in coastal sedimentary research, Coastline Reports, 17, 65-80, 2011.

Feldens, P., Schwarzer, K., Szczuciński, W., Stattegger, K., Sakuna, D., and Somgpongchaiykul, P.: Impact of 2004 Tsunami on Seafloor Morphology and Offshore Sediments, Pakarang Cape, Thailand, Pol. J. Environ. Stud., 18, 63-68, 2009.

Feldens, P., Schwarzer, K., Sakuna, D., Szczuciński, W., and Somgpongchaiykul, P.: Identification of offshore tsunami deposits on the shelf off KhaoLak (Thailand), Earth Planets Space, 64, 875887,2012

Fujiwara, O. and Kamataki, T.: Identification of tsunami deposits considering the tsunami waveform, an example of subaqueous tsunami deposits in Holocene shallow bay on southern Bobo Penisular, Central Japan, Sediment. Geol., 200, 295-313, 2007.

Geyer, W. R., Hill, P. S., and Kineke, G. C.: The transport, transformation and dispersal of sediment by buoyant coastal flows, Cont. Shelf Res., 24, 927-949, 2004.

Goff, J., Chagué-Goff, C., and Nichol, S.: Paleotsunami deposits, a New Zealand perspective, Sediment. Geol., 143, 1-6, 2001.

Goff, J., McFadgen, B. G., and Chagué-Goff, C.: Sedimentary differences between the 2002 Easter storm and the 15th-century Okoropunga tsunami, southeastern North Island, New Zealand, Mar. Geol., 204, 235-250, 2004.

Goff, J., Chagué-Goff, C., Nichol, S., Jaffe, B., and DomineyHowes, D.: Progress in palaeotsunami research, Sediment. Geol., 243-244, 70-88, 2012.

Goodman-Tchernov, B. N., Dey, H. W., Reinhard, E. G., McCoy, F., and Mart, Y.: Tsunami waves generated by the Santorini eruption reached Eastern Mediterranean shores, Geology, 37, 943-946, 2009.

Goto, K., Chavanich, S. A., Imamura, F., Kunthasap, P., Matsui, T., Minoura, K., Sugawara, D., and Yanagisawa, H.: Distribution, origin and transport process of boulders deposited by the 2004 Indian Ocean tsunami at Pakarang Cape, Thailand, Sediment. Geol., 202, 821-837, 2007.

Goto, K., Takahashi, J., Oie, T., and Imamura, F.: Remarkable bathymetric change in the nearshore zone by the 2004 Indian Ocean tsunami, Kirinda Harbor, Sri Lanka, Geomorphology, 127, 107-116, 2011
Goto, K., Hashimoto, K., Sugawara, D., Yanagisawa, H., and Abe, T.: Spatial thickness variability of the 2011 Tohoku-oki tsunami deposits along the coastline of Sendai Bay, Mar. Geol., 358, 38 48, doi:10.1016/j.margeo.2013.12.015, 2014.

Grzelak, K., Kotwicki, L., and Szczuciński, W.: Monitoring of Sandy Beach Meiofaunal Assemblages and Sediments after the 2004 Tsunami in Thailand, Pol. J. Environ. Stud., 18, 43-51, 2009.

Harris, P. T. and Heap, A. D.: Cyclone-induced net sediment transport pathway on the continental shelf of tropical Australia inferred from reef talus deposits, Cont. Shelf Res., 29, 2011-2019, 2009.

Hill, P. S., Fox, J. M., Croeckett, J. S., Curran, K. J., Friedrich, C. T., Geyer, W. R., Milligan, T. G., Ogston, A. S., Puig, P., Scully, M. E., Traykovski, P. A., and Wheatcroft, R. A.: Sediment delivery to the seabed on continental margins, in: Continental Margin Sedimentation, edited by: Nittrouer, C. A., Austin, J. A., Field, M. E., Kravitz, J. H., Syvitski, J. P. M., and Wiberg, P. L., IAS Special Publication 37, 49-99, 2007.

Hofmann, D. I., Fabian, K., Schneider, F., Donner, B., and Bleil, U.: A stratigraphic network across the Subtropical Front in the central South Atlantic, Multi-parameter correlation of magnetic susceptibility, density, X-ray fluorescence and $\delta^{18} \mathrm{O}$ records, Earth Planet. Sc. Lett., 240, 694-709, 2005.

Hylleberg, J., Nateewathana, A., and Chatananthawej, B.: Temporal changes in the macrobenthos on the West Coast of Phuket Island, with emphasis on the effects of offshore tin mining, Phuket Mar. Biol. Cent. Res. Bull., 37, 1-16, 1985.

Jankaew, K., Atwater, B. F., Sawai, Y., Choowong, M., Charoentitirat, T., Martin, M. E., and Prendergast, A.: Medieval forewarning of the 2004 Indian Ocean tsunami in Thailand, Nature, 455, 1228-1231, 2008.

Kale, V. S.: Geomorphic Effects of Monsoon Floods on Indian Rivers, Nat. Hazards, 28, 65-84, 2003.

Khokiattiwong, S., Limpsaichol, P., Petpiroon, S., Sojisuporn, P., and Kjerfve, B.: Oceanographic variations in Phangnga Bay, Thailand under monsoonal effects, Phuket Mar. Biol. Cent. Res. Bull., 55, 43-76, 1991.

Kortekaas, S. and Dawson, A. G.: Distinguishing tsunami and storm deposits, An example from Martinhal, SW Portugal, Sediment. Geol., 200, 208-221, 2007.

Krassay, A. A.: Storm features of siliciclastic shelf sedimentation in the mid-Cretaceous epeiric seaway of northern Australia, Sediment. Geol., 89, 241-264, 1994.

Krumbein, W. C.: Size frequency distribution of sediments and the normal phi curve, J. Sediment. Petrol., 8, 84-90, 1938.

Kuehl, S. A., Nittrouer, C. A., Allison, M. A., Ercilio, L., Faria, C., Dukat, D. A., Jaeger, J. M., Pacioni, T. D., Figueiredo, A. G., and Underkoffler, E. C.: Sediment deposition, accumulation, and seabed dynamics in an energetic, fine-grained, coastal environment, Cont. Shelf Res., 16, 787-815, 1985.

Lamy, F., Hebbeln, D., Röhl, U., and Wefer, G.: Holocene rainfall variability in southern Chile, a marine record of latitudinal shifts of the Southern Westerlies, Earth Planet. Sc. Lett., 185, 369-382, 2001.

Lario, J., Luque, L., Zazo, C., Goy, J. L., Spencer, C., Cabero, A., Bardají, T., Borja, F., Dabrio, C. J., Civis, J., González-Delgado, J. A., Borja, C., and Alonso-Azcárate, J.: Tsunami vs. storm surge deposits, a review of the sedimentological and geomor- 
phological records of extreme wave events (EWE) during the Holocene in the Gulf of Cadiz, Spain, Z. Geomorphol., 54, 301316, 2010.

Le Roux, J. P. and Vargas, G.: Hydraulic behavior of tsunami backflows, insights from their modern and ancient deposits, Environ. Geol., 49, 65-75, 2005.

Lim, H. S. and Boochabun, K.: Flood generation during the SW monsoon season in northern Thailand, Geol. Soc. S. P., 361, 720, 2012.

Lorang, M. S.: A wave-competence approach to distinguish between boulder and megaclast deposits due to storm waves versus tsunamis, Mar. Geol., 283, 90-97, 2011.

Malmon, D. V., Reneau, S. L., and Dunne, T.: Sediment sorting and transport by flash floods, J. Geophys. Res., 109, F02005, doi:10.1029/2003JF000067, 2004.

Martin, A. J.: Flaser and wavy bedding in ephemeral streams, a modern and an ancient example, Sediment. Geol., 136, 1-5, 2000.

McKee, B. A., Nittrouer, C. A., and DeMaster, D. J.: The concepts of sediment deposition and accumulation applied to the continental shelf near the mouth of the Yangtze River, Geology, 11, 631-633, 1983.

Milker, Y., Wilken, M., Schumann, J., Sakuna, D., Feldens, P., Schwarzer, K., and Schmiedl, G.: Sediment transport on the inner shelf off Khao Lak (Andaman Sea, Thailand) during the 2004 Indian Ocean tsunami and former storm events: evidence from foraminiferal transfer functions, Nat. Hazards Earth Syst. Sci., 13, 3113-3128, doi:10.5194/nhess-13-3113-2013, 2013.

Morton, R. A., Gelfenbaum, G., and Jaffe, B. E.: Physical criteria for distinguishing sandy tsunami and storm deposits using modern examples, Sediment. Geol., 200, 184-207, 2007.

Mulder, T., Syvitski, J. P. M., Migeon, S., Faugères, J. C., and Savoye, B.: Marine hyperpycnal flows: initiation, behavior and related deposits: A review, Mar. Petrol. Geol., 20, 861-882, 2003.

Nanayama, F. and Shigeno, K.: Inflow and outflow facies from the 1993 tsunami in southwest Hokkaido, Sediment. Geol., 187, 139-58, 2006.

Nanayama, F., Shigeno, K., Satake, K., Shimokaka, K., Koitabashi, S., Miyasaka, S., and Ishii, M.: Sedimentary differences between the 1993 Hokkaido-nansei-oki tsunami and the 1959 Miyakojima typhoon at Taisei, southwestern Hokkaido, northern Japan, Sediment. Geol., 13, 255-264, 2000.

Nott, J. F.: Waves, boulders and the importance of the pre-transport setting, Earth Planet. Sc. Lett., 210, 269-276, 2003.

Ogston, A. S., Cacchione, D. A., Sternberg, R. W., and Kineke, G. C.: Observations of storm and river flood-driven sediment transport on the northern California continental shelf, Cont. Shelf Res., 20, 2141-2162, 2000.

Ohta, T. and Arai, H.: Statistical empirical index of chemical weathering in igneous rocks, A new tool for evaluating the degree of weathering, Chem. Geol., 240, 280-297, 2007.

Owen, R. B. and Lee, R.: Human impacts on organic matter sedimentation in a proximal shelf setting, Hong Kong, Cont. Shelf Res., 24, 583-602, 2004.

Owens, P. N.: Soil erosion and sediment fluxes in river basins: the influence of anthropogenic activities and climate change, in: Soil and Sediment Remediation: Mechanisms, Technologies and Applications, edited by: Lens, P., Grotenhuis, T., Malina, G., and Tabak, H., IWA Publishing, London, 418-434, 2005.
Palinkas, C. M., Nittrouer, C. A., and Walsh, J. P.: Inner shelf sedimentation in the Gulf of Papua, New Guinea, a mud-rich shallow shelf setting, J. Coastal Res., 22, 760-772, 2006.

Panchang, R., Nigam, R., Raviprasad, G. V., Rajagopalan, G., Ray, D. K., and Hla, U. K. Y.: Relict faunal testimony for sea-level fluctuations off Myanmar (Burma), J. Palaeon. Soc. India, 53, 185-195, 2008.

Paris, R., Fournier, J., Poizot, E., Etienne, S., Mortin, J., Lavigne, F., and Wassmer, P.: Boulder and fine sediment transport and deposition by the 2004 tsunami in LhokNga (western Banda Aceh, Sumatra, Indonesia), A coupled offshore-onshore model, Mar. Geol., 268, 43-54, 2010.

Phantuwongraj, S. and Choowong, M.: Tsunamis versus storm deposits from Thailand, Nat. Hazards, 63, 31-50, 2012.

Postma, G.: Physical climate signatures in shallow- and deep-water deltas, Global Planet. Change, 28, 93-106, 2001.

Ramaswamy, V., Rao, P. S., Rao, K. K., Swe Thwin, Rao, N. S., and Raiker, V.: Tidal influence on suspended sedimen distribution and dispersal in the northern Andaman Sea and Gulf Martaban, Mar. Geol., 208, 33-42, 2004.

Ramírez-Herrera, M.-T., Lagos, M., Hutchinson, I., Kostoglodov, V., Machain, M. L., Caballero, M., Goguitchaichvili, A., Aguilar, B., Chagué-Goff, C., Goff, J., Ruiz-Fernández, A.-C., Ortiz, M., Nava, H., Bautista, F., Lopez, G. I., and Quintana, P.: Extreme wave deposits on the Pacific coast of Mexico, Tsunamis or storms? - A multi-proxy approach, Geomorphology, 139-140, 360-371, 2012.

Richmond, B. M., Watt, S., Buckley, M., Jaffe, B. E., Gelfenbaum, G., and Morton, R. A.: Recentstorm and tsunami coarse-clast deposit characteristics, southeast Hawaii, Mar. Geol., 283, 79-89, 2011.

Robbins, J. A. and Edgington, D. N.: Determination of recent sedimentation rates in Lake Michigan using Pb-210 and Cs-137, Geochim. Cosmochim. Ac., 39, 285-304, 1975.

Rodolfo, K. S.: Bathymetry and Marine Geology of the Andaman Basin, and Tectonic Implications for Southeast Asia, Geol. Soc. Am. Bull., 80, 1203-1230, 1969.

Sakuna, D., Szczuciński, W., Feldens, P., Schwarzer, K., and Khokiattiwong, S.: Sedimentary deposits left by the 2004 Indian Ocean tsunami on the inner continental shelf offshore of KhaoLak, Andaman Sea (Thailand), Earth Planets Space, 64, 931-943, 2012.

Schwab, J. M., Krastel, S., Grün, M., Gross, F., Pananont, P., Jintasaeranee, P., Bunsomboonsakul, S., Weinrebe, W., and Winkelmann, D.: Submarine mass wasting and associated tsunami risk offshore western Thailand, Andaman Sea, Indian Ocean, Nat. Hazards Earth Syst. Sci., 12, 2609-2630, doi:10.5194/nhess-122609-2012, 2012.

Shanmugam, G.: Process-sedimentological challenges in distinguishing paleo-tsunami deposits, Nat. Hazards, 63, 5-30, doi:10.1007/s11069-011-9766-z, 2011.

Singh, O. P., Ali Khan, T. M., and Rahman, M. S.: Changes in the frequency of tropical cyclones over the North Indian Ocean, Meteorol. Atmos. Phys., 75, 11-20, 2000.

Siripong, A.: Andaman Sea coast of Thailand Field Survey after the December 2004 Indian Ocean Tsunami, Earthq. Spectra, 22, 187-202, 2006.

Smedile, A., De Martini, P. M., Pantosti, D., Bellucci, L., Del Carlo, P., Gasperini, L., Pirrotta, C., Polonia, A., and Boschi, E.: Pos- 
sible tsunami signatures from an integrated study in the Augusta Bay offshore (Eastern Sicily-Italy), Mar. Geol., 281, 1-13, 2011. Smith, J. N.: Why should we believe ${ }^{210} \mathrm{~Pb}$ sediment geochronologies?, J. Environ. Radioactiv., 55, 121-123, 2001.

Snedden, J. W., Nummedal, D., and Amos, A. F.: Storm- and fairweather combined flow on the central Texas continental shelf, J. Sediment. Petrol., 58, 580-595, 1988.

Spiske, M., Piepenbreier, J., Benavente, C., and Bahlburg, H.: Preservation potential of tsunami deposits on arid siliciclastic coasts, Earth-Sci. Rev., 126, 58-73, 2013.

Spiske, M., Bahlburg, H., and Weiss, R.: Pliocene mass failure deposits mistaken as submarine tsunami backwash sediments - an example from Hornitos, Northern Chile, Sediment. Geol., 305, 69-82, doi:10.1016/j.sedgeo.2014.03.003, 2014.

Sugawara, D., Minoura, K., Nemoto, N., Tsukawaki, S., Goto, K., and Imamura, F.: Foraminiferal evidence of submarine sediment transport and deposition by backwash during the 2004 Indian Ocean tsunami), Island Arc, 18, 513-525, 2009.

Switzer, A. D. and Jones, B. G.: Large-scale washover sedimentation in a freshwater lagoon from the southeast Australian coast, sea-level change, tsunami or exceptionally large storm?, Holocene, 18, 787-803, 2008.

Szczuciński, W., Chaimanee, N., Niedzielski, P., Rachlewicz, G., Saisuttichai, D., Tepsuwan,T., Lorenc, S., and Siepak, J.: Environmental and Geological Impacts of the 26 December 2004 Tsunami in Coastal Zone of Thailand - Overview of Short and Long-Term Effects, Pol. J. Environ. Stud., 15, 793-810, 2006.

Thai Meteorological Department (TMD): The Climate of Thailand, available at http://www.tmd.go.th/en/archive/thailand_climate. pdf (last access: 11 June 2015), 2012.

Thampanya, U., Vermaat, J. E., Sinsakul, S., and Panapitukkul, N.: Coastal erosion and mangrove progradation of Southern Thailand, Estuarine, Coast. Shelf Sci., 68, 75-85, 2006.

Tipmanee, D., Deelaman, W., Pongpiachan, S., Schwarzer, K., and Sompongchaiyakul, P.: Using Polycyclic Aromatic Hydrocarbons (PAHs) as a chemical proxy to indicate Tsunami 2004 backwash in Khao Lak coastal area, Thailand, Nat. Hazards Earth Syst. Sci., 12, 1441-1451, doi:10.5194/nhess-12-14412012, 2012.
Tjallingii, R., Stattegger, K., Wetzel, A., and Phach, P. V.: Infilling and flooding of the Mekong River incised valley during deglacial sea-level rise, Quaternary Sci. Rev., 29, 1432-1444, 2010.

Uchida J. I., Fujiwara, O., Hasegawa, S., and Kamataki, T.: Sources and depositional processes of tsunami deposits, Analysis using foraminiferal tests and hydrodynamic verification, Island Arc, 19, 427-442, 2010.

Umitsu, M., Tanavud, C., and Patanakanog, B.: Effects of landforms on tsunami flow in the plains of Banda Aceh, Indonesia, and Nam Khem, Thailand, Mar. Geol., 242, 141-153, 2007.

Usiriprisan, C., Chiemchindaratana, S., Shoosuwan, S., and Chatrapakpong, Y.: Offshore exploration for tin and heavy minerals in the Andaman Sea, Department of Mineral Resources, Bangkok and UNDP, New York, 224 pp., 1987.

van den Bergh, G. D., Boer, W., de Haas, H., van Weering, T. C. E., and van Wijhe, R.: Shallow marine tsunami deposits in Teluk Banten (NW Java, Indonesia), generated by the 1883 Krakatau eruption, Mar. Geol., 197, 13-34, 2003.

Wadman, H. M. and McNinch, J. E.: Stratigraphic spatial variation on the inner shelf of a high-yield river, Waiapu River, New Zealand: Implications for fine-sediment dispersal and preservation, Cont. Shelf Res., 28, 865-886, 2008.

Weber, M.E., Niessen, F., Kuhn, G., and Wiedicke, M.: Calibration and application of marine sedimentary physical properties using a multi-sensor core logger, Mar. Geol., 136, 151-172, 1997.

Weidong, D., Baoguo, Y., and Xiaogen, W.: Studies of storm deposits in China, a review, Cont. Shelf Res., 17, 1645-1658, 1997.

Weiss, R.: Sediment grains moved by passing tsunami waves, Tsunami deposits in deep water, Mar. Geol., 250, 251-257, 2008.

Weiss, R. and Bahlburg, B.: A note on the preservation of offshore tsunami deposits, J. Sediment. Res., 76, 1267-1273, 2006.

Wheatcroft, R. A. and Drake, D. E.: Post-depositional alteration and preservation of sedimentary event layers on continental margins, I. The role of episodic sedimentation, Mar. Geol., 199, 123-137, 2003.

Wolanski, E. and Spagnol, S.: Environmental degradation by mud in tropical estuaries, Reg. Environ. Change, 1, 152-162, 2000.

Wright, L. D. and Nittrouer, C. A.: Dispersal of river sediments in coastal seas, six contrasting cases, Estuaries, 18, 494-508, 1995. 